\title{
Microbial Translocation in the Pathogenesis of Cardiovascular Diseases: A Microbiome Perspective
}

\begin{abstract}
Despite continuous advances in treatment options, Cardiovascular diseases (CVDs) remain the leading cause of death worldwide. In recent years, compelling evidences supporting the influence of an infectious component in the pathogenesis of CVDs are mounting to increase. The translocation of microbes from the gastrointestinal tract (GIT) has long been considered a normal phenomenon imperative for the microbial maturity of the GIT in both healthy humans and diseased individuals. However, the impact of increased microbial translocation in the clinical complications of systemic inflammatory diseases and surgically treated individuals has gained more importance in the past decades. More particularly, its influence on the microbiome in 'immunologically privileged' sites of the human body has been extensively studied in many systemic diseases. In this review, we analyse the circulating infectious components in CVDs from a microbiome perspective and confabulate the role of microbial translocation in maintaining the unstable blood microbiome and its influence in CVDs. We also hypothesise a strong association between microbial translocation and the presence of infectious circulating agents and discuss the markers of microbial translocation, which can be used in the prognosis of CVDs.
\end{abstract}

Keywords: Microbial translocation; Dormant circulating microbiome; Lipopolysaccharides; Peptidoglycans; Pathogenesis

\author{
Creative Review \\ Volume 8 Issue 6 - 2017 \\ Vasudevan Dinakaran* \\ Department of Clinical Immunology, Jawaharlal Institute of \\ Postgraduate Medical Education and Research (JIPMER), India \\ *Corresponding author: Vasudevan Dinakaran, \\ Department of Clinical Immunology, Jawaharlal Institute of \\ Postgraduate Medical Education and Research (JIPMER), \\ Puducherry-605006, India, \\ Email: dinakaran.svgev@gmail.com
}

Received: March 31, 2017 | Published: May 16, 2017

\section{Introduction}

Cardiovascular diseases (CVDs) remain the leading cause of death globally. Over the last century, cardiovascular disease (CVD) has burgeoned from a less impact disease to a leading cause of death and disability. By 2020, CVDs are projected to surpass infectious diseases as the leading cause of mortality and the number of deaths is estimated to reach 23.3 million by 2030 [1]. Blood is normally considered a sterile environment in healthy individuals [2]. But, it has been reported earlier that blood might contain microbes or their components even in healthier individuals $[3,4]$. After the initiation of studies on the human microbiome in the year 2008, microbes were identified to be a part of the normal healthy human system, outnumbering the human cells [5,6]. More interestingly, microbes were identified in the circulation in many chronic inflammatory diseases like cancer, rheumatism, liver diseases, kidney diseases, bowel diseases and cardiac diseases [7-12].

More particularly, microbes in circulation were found to play a major role in the pathogenesis of these diseases $[11,13]$. In cardiac diseases, it has been studied that metabolism of phosphatidylcholine by gut microbiota increases CVD risk $[14,15]$. Similarly, gut microbial metabolism of carnitine has been reported to promote atherosclerosis [16]. Increased level of plasma trimethyl amino oxide (TMAO) is associated with atherosclerotic burden and poor prognosis of peripheral artery disease $[17,18]$. Thus, a growing body of evidence supports the concept that systemic inflammation induced by microbial components plays an important role in the clinical complications of CVDs $[19,20]$.

The assumption that blood was a sterile environment for years was questioned by studies over the past decades reporting the presence of microbial component even in physiologically healthy individuals $[3,4]$. The availability of methods has made possible the detection of microorganisms which were not easily culturable earlier. Recent studies have brought sharply into focus microbes present in humans in the unculturable form and their state of dormancy [21,22]. These microbes or their products thereof, might be viable or dormant but their components do essentially play a significant role in immune regulation, increasing the susceptibility or resistance of the individual to various diseases. Nikkari et al. [3] speculated that there might be a normal population of bacterial DNA in healthy human circulation.

The evidence for the presence of blood bacterial microbiome in systemic diseases originated for the first time when Amar et al. [23] described the presence of microbiota in the circulation of a large population prone to obesity and diabetes [23]. It was found that as the population developed diabetes, the bacterial profile in their circulation varied largely, indicating that dysbiosis in tissue microbiota is associated with the onset of diabetes. Li et al. [4 detected the presence of a large number of bacterial and viral elements in the plasma of HIV-infected population as compared to healthy individuals [4]. Later, Amar et al. [24] described that dysbiosis in blood microbiota is associated with the onset of CVDs 
[24]. Rajendhran et al. [25] described a contrasting circulating microbiome profile in CVD population as compared to healthy individuals [25]. Interestingly, in all these studies, members of the phylum Proteobacteria were found to dominate the circulating bacterial population in CVD and diabetes. However, these studies were observational in nature and thus cannot demonstrate the causative role played by blood microbiota in these diseases. In the subsequent year, the same group described the presence of bacterial and viral elements in circulation by profiling the circulating DNA in CVD patients [26]. Recently, Lluch et al. [27] profiled a novel tissue microbiota for the first time in the tissue samples of healthy mice using an optimized 16S rRNA gene analysis pipeline [27]. The circulating virome was first studied in HIV-infected patients. Retroviruses were found to dominate the virome population in the circulation of HIV-AIDS patients as compared to eukaryotic viruses in healthy individulas $[4,28]$. However, in CVD patients, bacteriophages were found to be the predominant circulating viral flora [26]. Nevertheless, it cannot be ruled out that these bacteriophage sequences could be part of the circulating bacterial nucleic acid signatures.

The solid immunological barrier of the intestine is maintained by the intact microbial flora, the intestinal mucosal cells and a normal functioning immune system [29]. The increased movement of microbes and their products across the intestinal barrier to circulation results in microbial translocation. In chronic inflammatory diseases, these microbial components are not efficiently cleared by the reticuloendothelial system (RES) of spleen. This evokes a strong immune response from the system induced by circulating microbial components, responsible for the pathogenesis of these diseases. In addition, other studies have also reported the translocation of microbial components from the buccal cavity to circulation in oral diseases [30,31]. Bacterial and viral products are released into circulation through the microvasculature that provides blood supply to the oral tract. In addition, surgical and non-surgical treatments to the diseases of teeth and oral cavity have also been reported to result in elevated levels of circulating bacterial products, leading to systemic immune activation $[32,33]$. The activated immune response forms the basis for the pathogenesis of cardiac diseases.

Increased circulating immune response and their effects have been studied in many heart diseases, including atherosclerosis, arteriosclerosis, coronary heart disease (CHD), rheumatic heart disease (RHD) and other valvular diseases, cardiac ischemia, cardiac cachexia, heart failure, myocardial infarction (MI) and endocarditis [10,34-37]. Besides the classical risk factors of these diseases, studies over the past three decades have focused on the influence of a strong infectious component and inflammatory response on the pathogenesis and clinical sequelae of these diseases $[24,38,39]$. However, the disease complications are largely dependent on the extent of vascular infection by circulating infectious products leading to chronicity of the disease $[40,41]$. Microbial products, such as lipopolysaccharides (LPS), lipoteichoic acids (LTA), peptidoglycans, nucleic acids and flagellins in circulation have been reported to provoke a strong host immune response [42-45].

However, microbial products from the buccal cavity and gut are normally released into the circulation in healthy individuals which gets cleared off by the RES of liver. Microbes were detected in circulation after daily procedures like tooth brushing and mastication of food in the oral cavity $[38,46]$. Similarly, bacteria were detected in circulation after food intake and this process of translocation of bacterial products across the intestinal barrier into blood stream is considered a normal phenomenon essential for microbial maturity of the intestine $[47,48]$. This has led to a burgeoning interest in the mode of release of bacteria and viruses into circulation and the role of these microbial components in the pathogenesis of many systemic diseases.

In particular, the chronicity of certain cardiac diseases is strongly linked to dental procedures. Also, both surgical and non-surgical dental procedures lead to the release of microbial products in the circulation along the dental microvasculature. Similarly, surgical procedures in the liver (resection), kidney (hemodialysis), heart (coronary artery bypass graft) and stomach (peritoneal dialysis) induce extensive release of microbial products from gut into circulation [10,49-51]. Bacteremia induced by gutblood barrier dysfunction is commonly reported in chronic kidney disease (CKD), congestive heart failure (CHF), atherosclerosis, cirrhosis, obstructive jaundice, acute pancreatitis and end stage renal disease (ESRD) patients [51-56]. Similarly, bacteremia due to oral diseases such as periodontitis, endodontis, pulpitis and pulpotomy has been more widely reported in CVDs $[46,57,58]$. Intestinal microbial translocation has been extensively studied in HIV-infected patients and has been linked to CVDs, diabetes and tuberculosis [59-61]. Most notably, microbial translocation has been reported to be the primary reason for cardiovascular risk in HIV-infected patients [62, 63].

Bacterial LPS and their host receptors, CD14 are predominantly responsible for host immune activation [63]. Increased plaque burden in HIV-infected patients has been shown to be the primary reason for HIV-associated atherosclerosis [59]. It was recently studied that peptidoglycans released from the gut microbiota has the potential to enhance systemic immunity by stimulating neutrophils in the bone marrow [44]. LPS, released by Gram negative bacteria, acts on macrophages and monocytes to release cytokines, interleukins and chemokines and activates the complement system, thereby, evoking a strong circulating inflammatory response [64,65]. Increased circulating LPS levels activate both innate and adaptive branches of the immune system. The classical risk factors of CVD such as smoking, hypertension, hypercholesterolemia can trigger endothelial activation by expression of endothelial cell adhesion molecules, leading to the adhesion of monocytes to the inner arterial walls [66]. They cause polyclonal stimulation of B cells and induce macrophage activation.

LPS have been reported to be present in the dental tubules of infected root canals $[67,68]$. In another study, it was shown that the myocardial tissue itself synthesizes TNF $\alpha$ on exposure to LPS [69]. LPS in circulation also causes platelet activation [70] and induces dilation of resistant arteries [71]. LPS on interaction with LDL influences lipoprotein metabolism, and thereby promotes atherosclerosis [72]. The microbial products in the circulation are recognized by Toll-like receptors (TLRs) of the innate immune system present on the cell surfaces or on intracellular vesicles. Serum CD14 (sCD14) is expressed primarily by monocytes and 
binds to bacterial LPS in the presence of LPS binding protein (LBP) In end stage heart failure patients awaiting heart transplantation or assist devices, increased production of LPS stimulated TNF $\alpha$ has been reported [69]. LPS or LTA released during acute infection might activate plaque cells. LPS in dental plaques can infiltrate gingiva and elicit a systemic LPS specific antibody response $[32,73]$. LPS interacts with lipoproteins to produce modified lipoproteins contributing to local or distant infections resulting in the inflammatory process in atherosclerosis [74]. Bacterial DNA acts on the vascular and dendritic cells to release chemokines and cytokines through interaction with TLR9 [75].

Coronary blood flow is influenced primarily by endothelial cell mediated factors, metabolites and neurohormonal mechanisms. Coronary atherosclerosis is caused due to the deposition of lipid containing molecules in the tunica-intima of coronary arteries resulting in atherosclerotic lesion or plaque or atheroma Atheroma formation involves a complex set of mechanisms, involving, endothelial dysfunction, lipoprotein deposition, lipid oxidation in arterial walls, infiltration by inflammatory cells, smooth muscle cell (SMC) proliferation and matrix deposition. Endothelial dysfunction is the initial step in atherosclerosis resulting from exposure to reactive oxygen species (ROS) caused by smoking, or due to the effects of individual or a combination of risk factors like LDL, hypertension, infectious agents etc. Endothelial dysfunction results in the increased permeability to lipoproteins, increased expression of inflammatory molecules, adhesion molecules and release of chemotactic factors that attract inflammatory cells like monocytes, macrophages and lymphocytes and facilitate their migration into the arterial walls resulting in fatty streak.

Macrophages containing LDL form foamy cells. As more foamy cells, smooth muscle cells (SMCs) and inflammatory cells accumulate in the arterial wall, the fatty streak tends to grow in size to form a fibrous cap surrounding a lipid core resulting in atheroma or plaque formation. As the plaque grows in size, large enough to interfere with the blood flow; it pushes its way along the arterial lumen resulting in ischemia and angina. Angina may result due to MI, myocardial ischemia, arrhythmias, coronary artery disease (CAD), myocardial necrosis and heart failure. CAD results due to the narrowing of arterial lumen because of both atherosclerotic and non-atherosclerotic causes. Nonatherosclerotic causes include coronary dissection, coronary artery spasm, coronary embolism and microcirculation abnormalities, triggered by tobacco abuse, emotional stress and cocaine abuse. However, coronary embolism may also be caused by infected mitral or aortic valves, resulting in infective endocarditis (IE). The goal of CVD treatment through drugs is to lower the LDL levels to less than $100 \mathrm{mg} / \mathrm{dl}$ and increase the HDL levels to more than $40 \mathrm{mg} / \mathrm{dl}$. Surgical procedures for coronary artery revascularization, viz., cardiopulmonary bypass (CPB) and percutaneous coronary interventions (PCI) result in systemic inflammatory response syndrome (SIRS). SIRS is caused due to inflammation because of exposure to bacterial endotoxins leading to leukocyte and endothelial cell activation resulting in the release of cytokines, chemokines and complement factors.

Most of the cardiac valvular problems result in IE. Endocarditis is the inflammation of the inner endocardium of the heart and the diagnosis is established by demonstrating microorganisms in valvular vegetation or intracardiac abscess and by echocardiographic evidence. The formation of a sterile fibrinplatelet thrombus at the endothelial disruption site is the initiating event. Subsequently, bacteremia followed by repetitive thrombus formation leads to the development of valvular vegetation. The bacterial vegetation grows in size, sheds organisms, fragments and embolizes. Infective valvular vegetation results in localized tissue destruction leading to valvular regurgitation, pericarditis and the formation of paravalvular abscesses. Commonly reported entry sites of bacteria in cardiac infections include the root canals and gums in dental infections, and dental procedures, surgical procedures in the oral cavity, indwelling intravenous catheters, intravenous drug abuse, and infections of the skin, lungs, intestine and urinary tract [37,52,76-81]. Most of the congenital heart diseases (CHD) which are initially non-infectious, may turn infectious, most notably, co-arctation of aorta, valvular septal defects (VSDs), valvular stenosis, valvular regurgitation, aortic and pulmonary atresia.

\section{Dormant blood microbiome in healthy individuals}

Microbes or their components, therein, were identified in the circulation of healthy individuals in recent years [4,82], albeit, earlier, blood was considered an immunologically privileged environment of the body $[2,83]$. The evidence for the presence of microbes in anatomically privileged compartments such as blood has thrown light on their impact on host immune surveillance, and possibly, for an earlier uncharacterized role in underlying systemic diseases like CVDs. Very few studies have reported the presence of bacteria in healthy circulation. The most significant of these is the detection of intracellular bacterial L-forms or pleomorphic forms in clinically healthy human blood $[84,85]$. Some of the rare reports recognize that bacteria could survive intracellularly both inside white blood cells [2] and erythrocytes [86]. Interestingly, there is evidence that a large variety of bacteria can invade erythrocytes. Tedeschi et al. [87] showed the presence of Corynebacteria like forms inside human red blood cells by electron microscopic studies [87]. It was later; bacteria were detected in healthy human blood by amplification of the prokaryotic $16 \mathrm{~S}$ rDNA gene $[3,88]$. The availability of sequencing and microscopic methods have made possible the detection of microbial components in healthy circulation $[27,84,89,90]$.

The microbial components may remain dormant in circulation for years, either in the viable or non-viable state [21,22,91]. But, they were detected in meager amounts in the blood $[85,88]$. Nonproliferating or not immediately culturable bacterial forms have been identified in many recent studies $[93,94]$. The dormancy of microbes is either due to viable but non-culturable state or the bacterial persistence state. This dormant state enables microbes to evade the host immune system. In addition, earlier studies have reported that the dormant state of microbes plays a significant role in causing disease and providing them the ability to tolerate antibiotic treatment $[95,96]$. More recently, viruses were also identified in the circulation of healthy individuals $[97,98]$.

The detection of circulating non-proliferating microbes or their products were mainly possible because of sequence-based methods using small subunit ribosomal RNA, applied widely in clinical microbiology [99]. Microbial components in blood were also identified by the detection of bacterial LPS [100] or 
peptidoglycans [101] in the circulation of healthy individuals. Dormant bacteria in circulation can resuscitate during disease conditions and shed cell wall components such as LPS and peptidoglycans. Even if these cells are not viable (capable of replication), their nucleic acids can produce systemic effects by acting on cells and induce disease [102,103]. The genetic material of non-viable bacterial cells plays a vital role in many disease conditions by acting on host cells. Nevertheless, the source of bacterial and viral elements in the circulation of healthy individuals remains elusive. However, several investigations performed earlier assert that bacteria can translocate from the oral tract and intestine to blood in 'healthy' humans $[29,48,92]$. The source of microbes in circulation is mostly gut or oral tract, released during tooth cleaning and gentle mastication from the buccal cavity or during a normal phenomenon of bacterial translocation from the intestine.

\section{Circulating microbiome in CVDs}

In cardiac diseases, it has been reported that dysbiosis in the blood microbial communities could be reason for the clinical complications of CVDs [24]. Altered microbial components in blood (atopobiosis) have been identified to be the main reason for cardiovascular complications. Cardiac diseases are considered non-communicable and non-infectious. But, several reports over the past decades identify infectious components to be involved in the circulatory system of cardiac patients [12,104-106]. In recent years, low-grade chronic inflammation and bacteria or viruses involved in inflammatory processes have been proposed as strong factors associated with atherosclerosis and CVD events [107-109] In particular, recent reports identify dysbiosis or atopobiosis of circulating microbiota in cardiac patients and this could be responsible for the onset of cardiovascular pathogenesis $[24,25]$. Interestingly, similar studies also demonstrate the association of blood microbiota with the onset of diabetes $[23,60]$.

The evidence for the presence of blood bacterial microbiome in systemic diseases originated for the first time when Amar et al. [23] described the presence of microbiota in the circulation of a large population prone to obesity and diabetes [23]. It was found that as the population developed diabetes, the bacterial profile in their circulation varied largely, indicating that dysbiosis in tissue microbiota is associated with the onset of diabetes. Li et al. [4] detected the presence of a large number of bacterial and viral elements in the plasma of HIV-infected population [4]. Later, Amar etal. [24] described that dysbiosis in blood microbiota is associated with the onset of CVDs [24]. Rajendhran et al. [25] described a contrasting circulating microbiome profile in CVD population as compared to healthy individuals [25]. Interestingly, in all these studies, members of the phylum Proteobacteria were found to dominate the circulating bacterial population in CVD, diabetes and HIV patients. However, these studies were observational in nature and thus cannot demonstrate the causative role played by blood microbiota in these diseases. In the subsequent year, the same group described the presence of bacterial and viral elements in circulation by profiling the circulating DNA in CVD patients [26] Recently, Lluch et al. [27] profiled a novel tissue microbiota for the first time in the tissue samples of healthy mice using an optimized 16S rRNA gene analysis pipeline [27]. The circulating virome was first studied in HIV-infected patients. Retroviruses were found to dominate the virome population in the circulation of HIV-AIDS patients as compared to eukaryotic viruses in healthy individulas $[4,28]$. However, in CVD patients, bacteriophages were found to be the predominant circulating viral flora [26]. Nevertheless, it cannot be ruled out that these bacteriophage sequences could be part of the circulating bacterial nucleic acid signatures.

Bacterial and viral organisms in atherosclerotic plaques have also been studied earlier [108]. Dental infections provide a favorable background for the formation of atherosclerosis $[76,110]$. When microbes or their products gain access to the circulation, they bind to oxidized lipids and act as inflammatory stimuli causing vascular cell injury. In an earlier study, increased fibrinogen levels were found to be associated with Chlamydia pneumoniae infection in CAD patients [111].

\section{Inflammation due to Infection in CVDs}

In CVDs, such as atherosclerosis, inflammation is triggered by a number of factors. For example, atherogenic lipid particles infiltrate the tunica intima layer of coronary arteries and activate the inner endothelial cells. This in turn, stimulates the increased expression of adhesion and pro-inflammatory molecules, which attracts inflammatory cells [71]. Macrophages then take up lipids and form foam cells, which accumulates in huge amounts in these sites and contribute to the development of atheroma. Many T-cell populations migrate to these areas, leading to the formation of atherosclerotic plaque. The pathogenicity is aggravated by the presence of microorganisms in the vicinity of plaques, by eliciting immune response to antigenic stimulus. This may lead to the disruption and rupture of plaques, leading to leakage of the prothrombotic plaque core in circulation resulting in the formation of thrombus. The matrix metalloproteases (MMPs) lyse the plaque wall, disrupting the plaque core and facilitating the metastasis of plaques to other sites in the coronary arteries, thereby, aggravating the clinical complications. This chronic inflammatory process in the coronary arterial wall leads to collagen deposition, fibrosis and thickening of the arteries at the sites of inflammation [112].

The Toll-like receptors (TLRs) recognize conserved motifs on pathogens called pathogen associated molecular patterns (PAMPs) which include LPS of Gram negative organisms, teichoic acids of Gram positive organisms, glycolipids of mycobacterium and viral nucleic acids. Many exogenous PAMPs may be ligands for receptors in atherosclerosis. C. pneumoniae, P. gingivalis and CMV are ligands implicated in atherosclerotic plaques $[113,114]$. These bacterial and viral agents have been associated with an increased risk of atherosclerosis [115,116]. In addition, TLRs also recognize the molecular patterns of endogenous host material released during tissue damage called damage associated molecular patterns (DAMPs). The most extensively studied TLR is TLR-2, activated by the peptidoglycan cell wall component of Gram positive bacteria, followed by TLR-4, which recognizes LPS and TLR-9, which recognizes bacterial DNA. However, other bacterial products, such as, lipoproteins and heat shock protein 60 , could stimulate different TLRs. TLR- 2 and TLR- 4 have most extensively been studied in animal models of atherosclerosis. Furthermore, it was found that low-grade endotoxemia inhibited cholesterol transport in mice in vivo [117], implicating that TLRs 
in atherosclerosis can promote lipid uptake leading to foam cell formation and atherosclerotic lesion development. Cholesterol crystals can activate NLRP3 inflammasome in human and murine macrophages suggesting that these signals may be endogenous danger signals in atherosclerosis [118,119]. TLR-2 and TLR-4 have been best characterized in atherosclerosis and these receptors have been ascribed proatherogenic roles and thus inhibition of these receptors and their downstream molecules is the most recognized prospect for therapeutics using Pattern Recognition Receptors (PRRs). High mobility group box 1 elements (HMGB1) have earlier been proposed as mediators of vascular inflammation [120]. HMGB1 is being released by necrotic cells and macrophages or monocytes in response to external stimuli by bacterial end products.

However, vascular cells in vitro were found to show little or no response to TLR ligands on atheromatous tissues [121]. Cytokines and other proinflammatory agents generated at nonvascular sites can be released into circulation and taken up by vessel walls. Internalization of bacteria into cells, mediated by lipid rafts takes place by usurping the autophagic pathway [122]. Bacterial invasion into the vascular endothelial cells may trigger apoptosis of these cells. Most of these microbial components which gets internalized localizes within autophagosomes and thereby prevent autophagy or the formation of autophagolysosomes. Internalization of many bacteria can produce a 'privileged niche', where they persist in a dormant state evading host immune surveillance [123]. Certain bacteria also invade nonprofessional phagocytic endothelial cells Cell to cell contact between the infected and host cells increases the rate of bacterial transmission through the transcellular route [124].

Bacteria or their components also contribute to plaque destabilization and rupture, leading to the release of prothrombotic plaque core in circulation and thrombus formation [125]. This is due to bacteria dependent release of MMPs with the accompanying suppression of tissue inhibitors of metalloproteases [TIMPs] [112, 126]. Periodontal pathogens in atheromatous plaques activate macrophages to recognize modified LDLs by molecular mimicry, leading to foam cell formation and progression of atheromas [127]. In earlier studies, it was demonstrated that IgG antibody levels against $P$. gingivalis had a stronger association with carotid intima-media thickening $[128,129]$. Pussinen et al. [130] found that elevated serum antibodies were associated with edentulous and concurrent CHD [130]. Bacterial contact with the vascular endothelia and subsequent invasion and activation of the vascular endothelia may result in leukocyte recruitment to the infection site.

Bacteria can also get disseminated into circulation through the microvasculature following tooth cleaning and other dental procedures [32]. Upon internalization into endothelial cells, a limited number of bacteria are able to persist inside host cells for a longer time period, activating the host tissue and proinflammatory cascade. Within 24 to 72 hours of internalization, the bacterium switches to a dormant state, in order to persist. However, upon fusion with phagolysosomes, some bacteria can escape from the dormant state, egress into extracellular space and invade adjacent host cells, thereby perpetuating persistent low grade inflammation [131]. The presence of a variety of pathogens in atheromatous tissues underlies this mechanism of bacterial persistence in tissues and authenticates the infection exacerbated model of atherogenesis [132]. Two parallel avenues which exist for metastatic pathogen dissemination include bacteremia and leukocyte mediated systemic spread of bacteria. Thus, microbes or their products which gets translocated persist in circulation and attaches to vascular endothelial cells to initiate TLR signaling induced inflammatory cascade [45].

Endothelial cells play a predominant role in maintaining proper cardiovascular function through the production of factors that modulate vasodilation, inflammation, thrombosis and cellular proliferation in vascular cells [133]. The first step in the formation of atherosclerotic plaques is increased levels of circulating low density lipoproteins (LDL) which infiltrates through the tunica intima vascular layer and is being taken up by macrophages and scavenger cells. More triglycerides are converted into LDL in the liver which gets transported to other tissues. More amounts of oxidized LDL are produced in response to increased release of proinflammatory particles $[134,135]$. Normally, the intimal layer of the vascular cells is impermeable and so leucocytes cannot adhere. Proatherogenic factors like dyslipidemia (increased LDL levels), smoking, hypertension and diabetes can cause endothelial dysfunction. Higher levels of circulating oxidized LDL proteins were found in cigarette smokers, obese people, diabetic patients and people with insulin resistance [136,137]. Endothelial dysfunction leads to decreased vasodilation and deterioration of the proinflammatory and procoagulatory milieu allowing the LDL particles to enter the sub endothelial layer. Inside endothelial cells, LDL gets oxidized due to excessive free radical production. Oxidized LDL creates a procoagulant on the inner endothelial surface of the heart tissue leading to MI. Monocytes differentiate into macrophages and ingest oxidized LDL to form foam cells, resulting in the formation of fatty streak. Fatty streak contains oxidized LDL, lipid laden macrophages, aggregated platelets and vascular SMCs. As the fatty streak increases in size, foam cells die releasing their contents. This attracts more immune competent cells and expands the lipid rich necrotic core. This in turn, stimulates the increased expression of adhesion and inflammatory molecules (ECAM and VCAM), which attracts monocytes and lymphocytes [71]. Experimental evidences have shown that oxidized lipids induce expression of adhesion molecules on endothelial cells $[138,139]$. Vascular SMCs migrate to the intimal surface to form a fibrous cap resulting in atheroma. The atheroma expands to form a stable or unstable plaque. Stable plaques, when clinically silent may lead to Angina pectoris. When a vulnerable or unstable plaque ruptures, the highly thrombogenic necrotic core on contact with blood forms thrombotic clot. Thrombus occludes a coronary artery at the infected or inflamed site to develop into an acute coronary syndrome. Oxidized lipoproteins have earlier been isolated from artery plaques in vitro [72]. Atherosclerosis is an intricate disease characterized by progressive accumulation and deposition of lipids, cells and extracellular matrix leading to plaque formation.

A strong correlation has been reported between C. pneumoniae infection and severity of atherosclerosis [140]. Melnick et al. [141] showed the presence of Cytomegalovirus (CMV) DNA in the arterial specimens of more than $76 \%$ of atherosclerosis patients who underwent vascular surgery [141]. Seropositivity 
for HCV shows a positive association with carotid artery plaque and carotid intima-media thickening, independent of other risk factors for atherosclerosis [142]. Similarly, Herpes virus infection was reported to increase the accumulation of cholesterol and cholesteryl ester in cultured arterial smooth muscle cells [143]. Nakano et al. [144] reported the isolation of Streptococcus mutans from extirpated heart valves and atheromatous plaque specimens after surgery [144]. Koren et al. [145] detected key bacterial members of dental plaque in atherosclerotic plaques and identified a core "signature" species in the plaque microbiome which was found to vary among individuals [145]. Various periodontopathogenic bacteria such as Tannerella forsythia, Fusobacterium nucleatum, Prevotella intermedia, Porphyromonas gingivalis, Prevotella nigrescens and Actinobacillus actinomycetemcomitans have been detected in the atheromatous plaques in the coronary arteries of atherosclerosis patients, suggesting a strong relationship between periodontitis and atherosclerosis $[146,147]$. Different routes of bacterial delivery to the inflammatory site in vascular cells results in the formation of atheromas [148].

CAD results due to accumulation of atheromatous plaques within the coronary artery walls of myocardium and encompasses a range of diseases that result from atheromatous change in coronary vessels. CAD and stroke are caused due to atherosclerotic plaque formation. Non-atherosclerotic causes of CAD include coronary artery spasm, coronary anomalies, coronary embolism, coronary dissection, myocardial bridging, anemia, tachycardia and ventricular hypertrophy, triggered by tobacco usage, cocaine abuse, emotional stress etc. MI is mostly caused due to a vulnerable plaque in circulation, which on interaction with blood cells forms a stable thrombotic clot, the process being called Thrombosis. The thrombotic clot, when blocks the coronary artery, obstructing blood flow, results in MI. Unlike CAD or atherosclerosis, the coronary thrombotic clot in MI remains more stable after detachment and might not contain any infectious agents. The thrombotic clot in blood circulation to brain might result in Stroke.

Lipoprotein A, which is implicated in MI, inhibits plasminogen activation leading to the accumulation of fibrin clots on the endothelial surface [149]. Many cells, including platelets, endothelial cells, activated monocytes, macrophages, and SMCs are involved in the atherosclerotic plaques formation [150]. Endothelial injury can be because of bacterial inflammatory stimuli. Following this, the endothelial cells release a series of proinflammatory molecules such as chemokines, cytokines and cell adhesion molecules leading to the activation of SMCs, triggering endothelial cell death programs and vessel occlusion because of platelet aggregation and thrombus formation [151]. Activated leukocytes in the endothelial space continue the inflammatory cycle through the synthesis of pro-inflammatory molecules which degrade the surrounding extracellular matrix leading to further infection [152]. When blood flow is not restored, it might result in myocardial ischemia, and finally leading to myocardial necrosis. Acute MI causes stasis of intracardiac blood increasing the thrombus size in the setting of a hypercoagulable state. Left ventricular thrombosis is more common in MI and might result in purulent pericarditis or myocardial abscess. Atherosis leading to plaque formation in peripheral blood vessels supplying blood to other organs might result in arteriosclerosis.

Coronary artery disease (CAD) is caused by the accumulation of atheromatous plaques within the walls of coronary arteries of the myocardium. Several studies have shown the presence of $C$. pneumoniae signatures in $\mathrm{CAD}$ patients, indicating the association of $C$. pneumoniae infection with CAD [153,154]. Experimental inoculation of $C$. pneumoniae in coronary artery has been found to increase lipid accumulation and stimulate inflammatory response in mice [155]. Presence of C. pneumoniae in carotid arteries has been reported to elevate interleukin-6 (IL-6) in plaques and CRP level in the serum of carotid endarterectomy patients [156]. Ishihara et al. [156] reported higher detection rates of $P$. gingivalis, A. actinomycetemcomitans, $B$. forsythus, $T$. denticola and C. rectus in the coronary artery plaques of CAD patients [157]. A few periodontal pathogens have been shown to invade coronary artery tissues [158]. They also found a positive correlation in the detection rate of bacterial DNA in coronary stenotic plaque and dental plaque samples. M. pneumoniae seropositivity was found to be more prevalent in patients with CAD than without CAD (14\% versus $6 \%, p<0.01$ ) [159]. $H$. pylori has also been more often detected in CAD patients [160]. Viral infections, such as CMV and HCV have also been reported to be associated with the risk of CAD $[161,162]$.

Valvular heart disease (VHD), characterized by a damage or defect in the mitral, aortic, tricuspid or pulmonary valves may be congenital or acquired. Aortic valve degeneration is the most frequently reported $[163,164]$. Common abnormalities of VHD include mitral stenosis, mitral and aortic regurgitation. VHD resulting from rheumatic fever due to Group A Streptococci infection is referred to as rheumatic heart disease (RHD) [165]. Pathogenesis of RHD is mediated by autoimmune mechanisms induced by Streptococcal components, such as, the M proteins and group A carbohydrate. Streptococcal antigens immunologically mimic heart antigens [166]. Antibodies that cross react with Streptococcal antigens and human proteins stimulate adhesion molecules leading to chronic inflammation and increased cellular infiltration. CD14+ cells that cross react with heart tissue and Streptococcal antigens increase inflammation of heart lesions. A large number of monocytes that infiltrate valvular lesions produce inflammatory cytokines and the imbalance between these cells and T-helper cells in the valves contribute to the maintenance and progression of rheumatic valvular lesions. Several M-protein epitopes in Streptococcus species can induce cross reactive responses against human proteins [167]. The incidence of VHD is commonly a result of untreated streptococcal infections developing into acute rheumatic fever. In addition, VHD can also be caused by transient bacteremia which in turn is caused by trauma to mucosal surfaces densely populated with microbes. When untreated, bacteremia could progress into infective endocarditis, which may cause permanent damage to one or more heart valves.

Angina pectoris or chest pain is a common clinical complication of IHD. Obstruction of coronary arteries due to atherosclerotic or non-atherosclerotic causes may result in IHD. CAD, MI or atherosclerotic diseases may result in IHDs, most notably, myocardial ischemia. Myocardial ischemia is the result of an imbalance between oxygenated blood supply and demand. Continuous stress for a longer time period may precipitate 
myocardial ischemia. Coronary vasospasms can occur in the absence of Atherosclerosis. On the other hand, some patients may develop a transient increase in the degree of coronary artery obstruction as a result of platelet aggregation and thrombus formation.

Endocarditis is the inflammation of the inner endocardial wall or equivalent prosthetic heart surfaces due to inflammation or infection. In infective endocarditis (IE), heart valves do not receive sufficient blood supply. As a result, immune responses cannot be elicited from the heart valves via blood stream. Microbes that manage to reach the endocardium persist in the inflamed tissue and forms large vegetation leading to chronic inflammation. Most of the endocarditis cases are the result of bacterial infections and $50 \%$ of them were due to Staphylococci and Streptococci. Endocarditis cases due to fungal and viral infections have rarely been reported earlier. The vegetation formed by these infectious agents is comprised of a large inner layer of platelets, fibrin, erythrocytes, leukocytes, a middle layer of bacteria and an outer layer of fibrin. In endocarditis, pathogens colonize the innate valves or the endothelial valve lesions. Inflamed endothelia produce proinflammatory cytokines, integrins and certain tissue factors. These factors, in turn, attract fibronectin, monocytes and platelets to the inflamed site. Bacteria adhering to these sites further activate the inflammatory cascade by invading endothelium, causing apoptosis and endothelial damage. In addition, they also embed themselves and evade host immune defenses [168,169].

Bacteria deploy a wide range of virulence strategies, including, adherence to host cells, biofilm formation, host cell invasion, aggression and intracellular persistence. Upon adherence, bacteria can proliferate and form biofilms, which provides many advantages for the bacteria including strong adherence, nutrition, immune evasion and antibiotic tolerance. Endothelial cell adhesion is a prerequisite for host cell invasion and intracellular persistence. Pathogenicity of endocarditis includes valve colonization and vegetation maturation. Spontaneous deposition of platelet-fibrin aggregates on abnormal and inflamed endothelia, combined with a hypercoagulable state results in the formation of nonbacterial thrombotic endocarditis (NBTE). Increasing age, malignancy, disseminated intravascular coagulation (DIC), uremia, VHD, and intravascular catheters are predisposing factors of NBTE [170]. Abnormal immune functions and bacteremia might contribute to early valvular colonization [171].

The valvular endothelium is generally resistant to infection. However, mechanical lesions of the endothelium expose the underlying extracellular matrix proteins, leading to local inflammation, and deposition of fibrin and platelets. This forms a NBTE complex, prone to bacterial colonization. Mechanical valve lesions promote infection by all pathogens. During bacteremia, blood flow through a narrowed valvular orifice deposits bacteria at a site near the orifice, injuring the endothelium. Thrombotic material is deposited at the same site leading to the formation of bacterial or infective endocarditis. Endothelial trauma or lesions are caused by turbulent blood flow due to cardiac abnormalities. Valve scarring and calcification in rheumatic carditis or valve sclerosis in geriatric patients may also result in endothelial lesions. Interventional therapies during coronary angioplasty or
CABG, by prosthetic valve replacement or indwelling catheters may also cause endothelial cell lesions.

However, IE may occur without any identifiable pre-existing lesions. Local inflammation, which occurs in some cases, triggers endothelial cells to express a wide variety of molecules including integrins. $\beta 1$ integrins, for example, bind circulating fibronectin to the endothelial valvular surfaces. Thus, fibronectin bound by the activated endothelia provides an adhesive surface to the circulating bacteria. Inflammation and coagulation are very closely related. Tissue factor, which plays a major role in coagulation, is released from the monocytes and endothelial cells by stimulation of IL1 , which in itself is produced due to endothelial injury. In turn, endothelial cells and monocytes produce cytokines and integrins that favour the formation of NBTE and attachment of circulating bacteria. Once attached, microbes further maintain this vicious cycle that promotes vegetation growth in which they are secured from host defenses. The mode of infection by microbes may vary according to the infecting species.

CHD includes co-arctation of aorta, total and partial pulmonary venous connections, valvular leaflets, patent ductus arteriosus and septal defects. The most known complication is the obstruction of blood flow due to hypoxia or syncope. Congestive heart failure (CHF) is mostly the end stage of cardiac disease resulting due to severe damage to inner organs like kidney, liver etc. or heart muscle. However, CHF may also result as a later complication of surgical procedures like CABG and PCI. CHF results in cases of end stage renal disease (ESRD), acute renal injury, acute lung injury, liver cirrhosis, bile duct obstruction, bowel injury or intestinal reperfusion etc. Earlier evidences demonstrate the involvement of infectious components in heart failure [53]. In particular, circulating endotoxemia due to gut bacterial translocation has been widely studied in heart failure $[37,69]$. Pericarditis or pericardial abscesses involving the pericardial fluid is a strong proponent of cardiomyopathy. Pericardial thickening may result in constrictive pericarditis and restrictive cardiomyopathy. However, bacterial and viral infections of the pericardium due to thoracic surgery, or, as a complication of infective endocarditis or systemic bacteremia or contagious pleural, pulmonary infections may also result in pericarditis. Constrictive pericarditis due to thickening, fibrosis and calcification of the pericardium, encases the heart in a solid, non-compliant envelope.

\section{Microbial Translocation Across the Intestinal Barrier in CVDs}

The GIT functions as an effective immunological barrier against intraluminal pathogens from entering the circulation [172]. The intestinal barrier is maintained by a well-balanced microflora, intact mucosa and a proper functioning immune system. The Peyer's patches in the intestinal crypts, along with lymphocytes and macrophages form the innate immune defense system of the intestine [172]. The intestine also maintains a stable ecological balance to prevent bacterial overgrowth and subsequent translocation. When one or more of these protective mechanisms are impaired, viable microbes or their products may traverse this barrier and spread to the mesenteric lymph nodes or other organs through lymphatic drainage and circulation resulting in microbial translocation. However, this process was also known 
to occur in the healthy human intestine $[173,174]$ and appears to begin early in life [47]. The microbial products in circulation will be cleared off regularly by the RES of liver $[175,176]$. However, the dormant microbes or their components are known to persist in circulation in diseased conditions. The enterocytes are held together by tight junctions. The movement of bacteria occurs either through the transcellular route involving enterocytes or the paracellular route involving tight junctions. On the other hand, the movement of bacterial products takes place in between enterocytes through the paracellular route [29]. The movement of bacteria and viruses from the gut to other parts of the human body involves a complex immunological process $[92,98,177]$. The most known source of entry of microbes into the circulation from the gut is by direct cellular uptake through the activation of NOD1 receptors in M cells overlaying the Peyer's patches by damage to the gut epithelial cells $[178,179]$.

It has been studied earlier that, in the normal human gut, bacterial outer membrane fragments are constantly shed into the circulation during replication and circulating endotoxins are present without any harmful effects $[173,174]$. Circulating endotoxemia has been reported earlier in cardiac patients [10], albeit, it has been frequently reported in gut diseases such as the bowel disease and liver disease [55,180]. Many immunological mechanisms support the concept that gut leakage is primarily responsible for the higher levels of circulating microbial components [181]. These microbial components accumulate in the fatty acids of arterial walls leading to the degradation of vascular endothelium in CVDs.

The maintenance of normal epithelial cell structure prevents the transepithelial migration of microbial particles from the gut lumen and the tight junctions prevent movement through the paracellular route [182]. Bacteria initially adhere to the enterocytes and bind to receptors on the cell membrane and this allows them to reach the basal membrane. The intestinal lymphatic drainage carries the bacteria to mesenteric lymph nodes from where they spread to other tissues through circulation [183]. Bacterial components gain access to systemic circulation via the enteric venous system to the portal vein or following lymphatic drainage from the intestine. Some of the biologically harmful effects of LPS include intravascular coagulation [184], hemodynamic disturbances [185], metabolic derangemements [186], coronary artery revascularizartion [187], vascular endothelial damage [188] and cholestasis [189]. In addition, in other studies, suppression of cellular immunity and increased protein degradation from gut were seen [49]. Protein loss from the gut has been reported in CHD patients and may contribute to cardiac cachexia [190]. The gut epithelial cells which endocytose the bacteria are considered non-professional phagocytes. Portal vein endotoxemia of gut origin is considered a normal physiological phenomenon [9]. Interestingly, earlier studies have reported the translocation of microbes through enterocytes by a mechanism different from classical phagocytosis and exocytosis.

Subsequently, the uptake of microbial components from the circulation takes place by the endothelial and kupffer cells of liver through both receptor dependent and receptor independent endocytic mechanisms. The translocating bacteria can be cultured from the mesenteric lymph nodes and other extra-intestinal sites only if they survive translocation through the lamina propria and are not removed by host immune mechanisms. Macrophages are important effector cells in the defense against translocation. Receptor dependent internalization of pathogenic particles takes place by binding to the complement $\mathrm{C} 3$ or Fc receptors or both, inducing phagocytosis. The capacity of liver to clear these particles is dependent on the number of particles that bind to these receptors. Extensive movement of bacteria is seen in case of intestinal wall damage which may occur due to ischemia, trauma, hypothermia, presence of vasoactive agents etc [191].

However, bacterial translocation from gut is controlled by its own flora by a process called colonic resistance. The normal intestinal anaerobic flora acts as a control mechanism in regulating the translocation of enterobacteria. Anaerobic bacteria are not readily taken up by enterocytes and stay attached to the epithelial receptors. This is proved by the finding that the translocation of anaerobic bacteria is facilitated in conditions of extensive histological damage to the intestinal epithelium, and thereby damage to the receptor sites [180]. Facultative intracellular bacteria translocate more readily than extracellular bacteria. Bacteria, such as Salmonella and Listeria can survive and replicate inside host blood cells. Hence, it has been studied that bacterial translocation is promoted by increased intestinal permeability, impaired host defense and bacterial over growth. Changes in intestinal permeability are caused by the loss of tight junction integrity or by cell wall injury at villous tips. These mechanisms can act synergistically to promote translocation and systemic spread of bacteria to cause sepsis.

In a study by Sato et al. [60], Gram positive anaerobic intestinal bacteria were isolated from the systemic circulation of Type 2 diabetic patients suggesting the movement of bacteria from gut to blood stream [60]. LPS from Gram negative bacteria binds to LDL and influences lipoprotein metabolism, thereby contributing to the development of atherosclerosis [192,193]. LPS induces endothelial cell damage $[194,195]$ or exerts stress on the vascular cell surface to stimulate excessive production and release of superoxide anions [20,196] resulting in LDL oxidation [197]. Oxidized LDL leads to atherosclerosis and the release of cytokines such as, IL-1 and TNF $\alpha$ from macrophages stimulate their transformation into foam cells $[134,135]$.

Microbial translocation is normally assessed in blood by the measurement of bacterial products such as, LPS [34], bacterial DNA or RNA fragments [54,198], serum CD14 levels [199], LBP levels [200], intestinal fatty acid binding protein (i-FABP) levels [201], endotoxin core antibodies and antiflagellin antibodies $[200,202]$. An alternative method used to assess microbial translocation is the detection and quantification of $16 \mathrm{~S}$ rDNA gene in plasma [54]. In many studies, bacterial $16 \mathrm{~S}$ rDNA gene was used as a marker of microbial translocation in HIV-infected patients $[63,65]$. Bacterial translocation occurs spontaneously when the intestinal barrier is compromised and the translocated microbial components activate plasma protein cascades, macrophages and neutrophils to release monokines and proteins.

LBP synthesized by liver is is a marker of atherosclerosis. However, LBP levels only reflect Gram negative bacterial infection and not Gram positive bacterial translocation, which is a major 
drawback in the assessment of MT in CVDs. However, presence of peptidoglycans in circulation has not been reported in CVDs, although, it has been reported in studies on hemorrhagic shock [203]. Most of the bacteria detected in blood are Gram negative and facultative anaerobes. Obligate anaerobes are not taken up by enterocytes and stay attached to the receptor sites on the epithelium [204].

\section{Viral translocation across the intestinal barrier}

While there are too many reports on the translocation of bacteria from gut, reports on viral translocation from the gut are relatively less and there are no reports in CVDs. More particularly, there are more reports on phagemia (presence of bacteriophages in circulation) than viremia (viruses in circulation). While bacterial movement to blood has been detected in healthy people, with a frequency of 5\% of the assayed population [205], there are no reports on viral translocation from gut in healthy individuals as on date. However, viruses and phages have been reported in the circulation of healthy individuals earlier [89,90]. Although, there are some reports on viral translocation in certain diseases, there is only one report on viral translocation in CVDs [206]. HIV translocates through the epithelium via M-cells, epithelial cells and dendritic cells to disseminate to systemic sites [207]. Evidently, phage translocation in diseased individuals will be much higher than in healthy individuals, as the intestinal barrier in diseased individuals is much more permeable to microbes than in healthy individuals. In an experiment on viral translocation in CVDs, influenza virus inoculated through the intra-tracheal route in Apo-E deficient mice, was detected in aortic plaques by quantitative PCR, immunohistochemistry and viral culture [206].

Phages in the gut interact with enterocytes and Gut associated lymphoid tissue (GALT), an immunological network comprising majority of T-cells and a significant B-cell compartment [208]. Phages may translocate through the enterocytes which constitutively express key elements for antigen processing and production of exosomes. These cells also express CD41a and CD61, which may be implicated in binding T4 phages [209]. In a study on phage therapy, it was found that dendritic cells phagocytose T4 phages rapidly and abundantly in contrast to bacteria, and phages inhibit phagocytosis of subsequently provided bacterial particles [210]. Therefore, phages could limit bacterial translocation by directly eliminating sensitive bacteria and gut inflammation, but increasing circulating bacterial components. It is also known that phages can interact with CD40/CD40 ligand system which is believed to play a major role in inflammatory reactions involving the GIT [211]. Many potent biological activities mediated through this pathway are exerted by activated platelets, including the ability to induce metastasis and angiogenesis [212]. These functions are implicated in atherosclerosis, diabetes and inflammatory bowel diseases. T4 phages on adhesion with human platelets inhibit their ability to interact with fibrinogen [213]. Thus, phage passage across the intestinal lumen is determined by a number of factors, viz., phage concentration and specific sequences within the phage capsid which interact with the enterocyte receptors, and phages interacting with dendritic cells.

\section{Bacterial Translocation from the Oral Cavity}

The other main source of entry of microbes into the circulation of cardiac patients is from the oral tract. Most studies have reported a strong influence of periodontal disease on CVD $[214,215]$. Transient bacteremia can occur in patients with chronic oral infections for years. Bacteria have been detected in blood after tooth brushing, tooth extraction and periodontal surgery [77]. Oral infections like dental caries lead to destruction of enamel, root surfaces of teeth, dentin and the components of periodontium. It was found that oral biofilms contain atleast 400 different bacterial species creating a highly organized microbial ecological system to perpetuate infection [77]. Translocation through the oral route has been reported in many studies earlier [39, 132,216,217].

Dental caries is usually formed by the initial infection of Streptococci, which are the early colonizers of the biofilm. Actinobacillus actinomycetemcomitans, Porphyromonas gingivalis, Tannerella forsythia and Treponema denticola are other significant colonizers identified in the oral cavity of periodontal disease patients. These organisms which form biofilms on tooth surface continuously shed microbial products, virulent components and metabolites. This invokes the host to produce a dense infiltrate of inflammatory cells and a variety of cytokines resulting in platelet aggregation and adhesion, cholesterol deposition and formation of lipid laden cells in the periodontal cells. The bacterial species release a surface protein called platelet aggregation associated protein which induces the aggregation of platelets released through injured capillaries. Bacteremia due to these infections can contribute to the risk of acute thromboembolic events associated with atherosclerosis and MI.

Oral biofilms have an organized structure, engrossed with bacteria in a matrix of salivary glycoproteins and extracellular polysaccharides. Periodontal diseases which includes Periodontitis and Gingivitis may affect one or more of the periodontal tissues supporting the tooth viz., the alveolar bone, periodontal ligament, cementum, and gingiva [218]. Periodontal infection is initiated by specific invasive oral aerobic and anaerobic bacteria that colonize dental plaque biofilms on the root surface of teeth. Periodontitis is characterized by a host inflammatory response against microbes and their products in dental plaques [219]. Helicobacter pylori have been detected in subgingival plaques of periodontal disease patients. Most of the organisms which are oral commensals when introduced into the circulation may become pathogenic. Streptococcus viridans has been more often implicated in endocarditis [220,221]. Inflammation plays an important role in atherothrombogenesis and its clinical complications, the potential causes of chronic inflammation, being infection with various bacterial agents [222,223].

In oral diseases, there is a fundamental shift in microbial communities was found to correlate with the intensity of disease progression [145]. P. gingivalis, in particular, is well studied to cause dysbiosis in oral disease $[224,225]$. Bacteria are not capable of directly invading oral tissues. The loss of epithelial integrity within the periodontal pockets due to inflammation facilitates bacterial translocation and induces bacteremia [38,226]. Bacterial infections in endodontis have also been implicated in CVDs $[58,73,227,228]$. Various dental procedures and routine oral hygiene efforts may lead to the entry of bacterial products into bloodstream; therefore bacterial products triggering a 
systemic immune response may form the basis for the link between periodontitis and coronary heart disease $[31,229,230]$. Various dental procedures, daily oral hygiene efforts and gentle mastication may lead to the translocation of bacteria or bacterial products from the oral cavity into blood stream and these bacterial components may lead to CVDs. Therefore, bacterial antigens and endotoxins in circulation triggering a systemic inflammatory response may represent the relation between oral infections and CVD. Common oral bacteria detected in atheromatous plaques include A. actinomycetemcomitans, T. forsythia, $P$. gingivalis, $P$. intermedia, E. corrodens and T. denticola [224, 231].

In 1994, Debelian observed that human periodontal and endodontic infections were associated with complex microfloras; approximately, 350 bacterial species were identified in marginal periodontitis and other 150 species were found in apical periodontitis [232]. The proximity of microflora present in root canal and periapical tissues to the bloodstream can cause transient bacteremia during clinical dental procedures viz., tooth extraction, periodontal and endodontic treatments. It is thus evident that both endodontic surgical procedures and non-surgical instrumentation of root canals during endodontic treatments can produce a transient bacteremia.

\section{Movement of bacteria to the circulation in Periodontitis}

Oral cavity contains a plethora of microbes, predominantly bacteria. Oral diseases result in the inflammation of supportive structures of teeth, including gums and alveolar bone. Plaque accumulation on tooth surface leads to bacterial infection in the periodontium. Intact crevicular epithelium of the gingival sulcus is non-permeable to bacteria. But it is permeable to bacterial antigens, metabolites and enzymes. A highly evolved interaction between bacteria and host leads to bacterial colonization of the gingival crevice by evading host defences and damage the crevicular epithelial barrier and integrity. Bacteria colonize the gingival sulcus by causing direct damage to Polymorphonuclear leukocytes (PMNLs) and macrophages, reduce PMN chemotaxis, modulate cytokines viz., IL-1 to 10 , IFN and TNF $\alpha$, degrade fibrin and alter lymphocyte function. They damage the epithelial barrier by releasing volatile Sulphur compounds and oral thiols, cause putrefaction and lead to oxygen deprivation, increasing oral and sulcar epithelial damage and induce disaggregation of proteoglycans and glycoproteins in the extracellular matrix.

They cause tissue damage by releasing hydrolytic enzymes such as, hyaluronidases, chondroitinases, neuraminidases, phospholipases, alkaline phosphatases etc. and proteolytic enzymes such as proteases, collagenases, cysteine proteases, gelatinases, trypsin like proteases etc. They degrade tissues by the release of leucotoxins and LPS; stimulate inflammation by activation of the complement system, destructs soft tissues by the production of ROS, lysozymes and collagen resulting in ECM destruction and extirpates alveolar bone by regulating bone activation and osteoclastic function in bone resorption. Bacteria cause indirect tissue damage by plaque intrusion, monocyte activation, and ligament and bone destruction. Bacterial antigens from plaques stimulate monocyte activation to produce high concentrations of tissue cytokines. They also stimulate matrix metalloproteases (MMPs), osteoclastic activity and alveolar bone destruction. The bacterial compounds impair oxygen utilization by host cells, react with cellular proteins, interfere with collagen maturation, increase collagen solubility, decrease DNA synthesis and proline transport and reduce the protein content of fibroblasts.

\section{Relationship between bacteria, inflammatory cells and bone resorption}

Bacteria release LPS which activates inflammatory cells resulting in the release of cytokines and local factors. These factors can act directly on osteoclasts to stimulate their activity as well as pre-osteoclasts to increase the pool of bone resorbing cells. The bacterial cells and inflammatory components may act directly on osteoblasts or their progenitors, resulting in decreased number of functional cells. It also results in bone loss and connective tissue attachment.

\section{Initial lesions during first 2 weeks after plaque accumulation:}

Vascular changes include dilation of arterioles, capillaries and venules, increased hydrostatic pressure, increased intracellular gap between endothelial cells and increased permeability of vessels, release of fluid and protein exudates from tissues and increased gingival crevicular fluid. Inflammatory reactions include migration of leukocytes from blood vessels, increased neutrophil population in gingival sulcus, junctional epithelium and connective tissues, acute inflammation with reddening and bleeding of tissues.

\section{Early lesions during second week of plaque accumulation}

Vascular changes include more number of dilated vessels and enhancement of local effects. Inflammatory reactions include increased neutrophils and lymphocytes, shift in cell population with an increase in the number of lymphocytes and macrophages and persistence of acute chronic inflammation. Reddening, swollen and bleeding of tissues with increased number of reteprocesses formation in junctional epithelium and degeneration of fibroblasts was seen.

\section{Established lesions formed 3 to 4 weeks following plaque accumulation}

Inflammatory reactions include features of chronic inflammation with increased lymphocyte population, B-cell maturation into plasma cells, more collagen loss and extension of deeper epithelial rete-processes. Red and swollen tissues are seen as in chronic gingivitis.

\section{Advanced lesions}

Inflammatory reactions include chronic inflammation, collagen loss, marked bone and attachment loss, mobility and tooth loss and formation of abscess. Infection sites include supragingival plaque area, root surface, radicular cementum or dentine, pocket lining and soft tissues within the pocket wall. Some bacteria also interfere with the normal host defense mechanism by inhibiting the action of phagocytic cells [219]. Advanced lesions cause 
degradation of collagen by MMPs 1 and 8 secreted by connective tissue fibroblasts. This leads to bone resorption by subgingival bacteria and bacterial components like LPS, LTA and Gram positive surface associated material.

\section{Entry of bacteria from the periodontium into blood stream}

Some of the supragingival plaque flora and subgingival flora invade cementum and radicular dentine and move to the microvasculature and enter the systemic circulation.

\section{Movement of bacteria to the circulation in Endodontis}

Apical periodontitis or pulpal inflammation is the late consequence of an endodontic infection caused by the persistence of coronal caries in the root canal system of teeth leading to the accumulation of bacterial plaque. It is characterized by the presence of bacteria in association with viruses and fungi in the root canals or endodontium of the diseased teeth organized in a biofilm, as a result of pulpal infection or a deep carious lesion [233]. The pathogenesis of this disease is due to a non-specific inflammatory process and a specific host immune reaction in the periapical tissues in response to infection from the endodontium. With time, this causes reabsorption of the periapical bone, its substitution with the inflammatory tissue and the formation of a periapical lesion. Clinical symptoms associated with different stages of apical periodontitis are represented by swelling of soft tissues, presence of sinus tract, pain to tooth percussion and palpation of the periapical area. Despite having a different etiology and pathogenesis, periodontal disease and endodontis share a common microbiota, often anaerobic Gram negative bacteria $[67,234]$ and are accompanied by elevated systemic cytokine levels [235,236].

Three possible metastatic pathways were considered responsible for the consequences of oral infections on CVD: metastatic spread of infection from oral cavity resulting from a transient bacteremia; metastatic injury by circulating oral microbial toxins and metastatic inflammation arising from an immune response to oral microorganisms [237]. The chronic activity of bacteria, their toxins, enzymes and metabolites, followed by the host immune response, leads to a progressive failure of periodontal attachment and premature loss of teeth. CRP has been detected in the gingival crevicular fluid in endodontis cases. However, it is not known whether CRP originates from serum or is synthesized in the extra-hepatic local tissues [238,239].

Furthermore, clinical procedures performed by dentists on the teeth and periodontium, along with brushing daily produces a transient bacteremia and may cause a secondary infection in a distant tissue or organ, including arteries. Patients with unfinished root canal treatment (RCT) in endodontic infections were reported to have higher incidence of CHD [58,240]. RCTs were normally performed to disinfect the microbial flora in the pulp, thereby, eliminating the microorganisms from the root canal system. Unfinished RCTs can create dead space aiding bacterial growth which can spread to other body sites. The root canal flora of teeth with intact crowns and necrotic pulps is dominated by obligate anaerobes [241]. An unfinished RCT with dead space can increase the risk of microflora contamination in the root canals over time and this leads to the progression of inflammation to periapical tissues, resulting in apical periodontitis [68,242]. The host tries to confine and restrict the infectious elements to the pulp. However, when unbalanced, as in RCT, this induces an acute spread of infection. A reasonable mechanism is that the infectious processes associated with the root canal system may not only cause localized symptoms in the oral cavity but also extend to other organs through systemic circulation.

The bacteria in the inflamed pulp and periapical granulomatous tissues can elevate inflammatory mediators and cytokines like IL-6 and IL-2 [243-245]. In another study by Garrado et al. [246], it was found that CRP was produced in apical lesions of endodontic origin in response to IL-6 release and its action on effector organs [246]. This low grade chronic inflammation for years, might lead to low grade infection and contribute to the development of atherosclerosis and CVD because these mediators can induce endothelial dysfunction $[13,235]$.

\section{Bacterial Translocation from the Oral Cavity in CVDs}

The association between dental infections and MI was reported for the first time in 1989 [247]. People with heart problems or coagulation abnormalities and those with artificial joints are found to be vulnerable to oral infections [248,249]. An acute episode of any infectious disease may play a vital role in precipitating a cardiovascular event without being involved in the progression of atherosclerosis. Damaged endothelia also trigger platelet aggregation and initiate thrombus formation at the injured site, resulting in vessel occlusion [151]. In carotid atherosclerosis, tunica intima-media thickening was found to increase with higher levels of circulating periodontal bacteria [129]. Beck and Offenbacher, [129] and Beck et al. [129] reported increased circulating antibody levels to periodontal microbes in coronary heart disease and subclinical atherosclerosis patients [128,250]. Spahr et al. [251] found that increased circulating pathogen burden was related positively to coronary heart disease [251]. C. pneumoniae, a pathogen commonly linked with atherosclerosis is able to spread from the respiratory tract to other tissues via circulation [252]. Periodontal bacteria, such as, A. actinomycetemcomitans and its components have been identified in circulation and these bacteria could have access to the circulation through bleeding periodontal pockets [31]. Both these bacteria have been detected in human atherosclerotic plaques $[147,253,254]$. Tooth loss was well correlated with increased coronary risk, in particular, among subjects with a positive history of oral disease. However, it is known that in VHD patients , a transient bacteremia may persist leading to IE and myocardial or cerebral infarction. Patients with one or two unfinished RCTs have a higher risk of CVD incidence than patients with three or more unfinished RCTs. In two studies performed earlier, it was found that the number of endodontic lesions was significantly associated with the diagnosis of CHD [255,256]. Additionally, in another study, it was found that dental patients with MI had a higher number of radiographic apical lesions compared with patients without MI [73]. Bacteremia was elicited in 31-54\% of RCT patients $[257,258]$. 
Though, there are differences in CVDs of periodontal or endodontic origin, there are similarities regarding common existing microbiota, predominantly, Gram negative bacteria $[234,259]$ and systemic cytokine levels in circulation [236]. Thus, chronic oral inflammation is a strong risk factor for heart diseases. Dental procedures are more often implicated in the etiology of IE $[260,261]$. Bacteremia of dental origin is more often implicated in IE. There are increasing evidences that exposure to bacteremia is significantly higher due to cumulative daily procedures such as tooth cleaning and mastication than due to surgical dental procedures [262]. The most important complication of IE is heart failure resulting due to the direct effects of proliferating bacterial vegetation on heart values. Embolism of vegetation fragments can damage organs and tissues including the brain, lungs, coronary arteries and spleen [263]. Herpes Simplex virus-1 and 2, Epstein Barr virus, Varicella Zoster virus, Human Herpes virus-7, human $\mathrm{CMV}$ and human Papilloma virus were detected in very few cases of endodontic pathosis $[57,264]$.

\section{Viral translocation from the buccal cavity}

There are no reports on viral translocation from the oral tract in healthy individuals as on date. However, viruses identified in the oral tract were detected in the circulation of healthy individuals [233]. Viruses have been implicated more frequently in oral disease associated CVDs and the majority of them were Herpes viruses. Cytomegalovirus (CMV) infection was identified more often in arteriosclerosis after cardiac transplantation [161]

\section{Pathogenesis of circulating microbial components in CVDs}

\section{Effect of circulating LPS on the vascular endothelia}

Circulating microbial components accumulate in fatty acids of arterial walls leading to the degradation of vascular endothelium in CVDs. Some of the biologically harmful effects of LPS include intravascular coagulation [184], hemodynamic disturbances [185], metabolic derangemements [186], coronary artery revascularizartion [187], vascular endothelial damage [188] and cholestasis [189]. It has been demonstrated that LPS derived from A. actinomycetemcomitans and C. pneumoniae transforms macrophages into lipid laden foam cells in vitro [265,266]. LPS on interaction with endothelial cells induces endothelial cell damage through oxidative stress by the production of superoxide ions. LDL gets oxidized on interaction with these superoxide ions and the oxidized LDL gets deposited on damaged endothelial cells. This can elicit an inflammatory response as demonstrated by increased concentrations of inflammatory markers, such as serum amyloid A (SAA), CRP and TNF $\alpha[36,267]$. The foam cell formation of arterial macrophages is attributable to reduced cholesterol transport by binding to high density lipoproteins [HDL]. During inflammation, there is an alteration in the amount of cellular surface components involved in reverse cholesterol transport. Thus, inflammation promotes lipid accumulation and formation of foam cells. Under pathophysiological conditions, the vascular endothelial functions are compromised impairing vasodilation regulated by endothelial Nitric oxide synthase (eNOS) activity inhibited by HDL. However, during inflammation, the amount of HDL is decreased resulting in the impairment of vasodilation.
Inflammatory mediators also enhance monocyte adhesion by inducing adhesion molecules, such as intercellular adhesion molecule (ICAM), vascular cell adhesion molecule (VCAM) and E-selectin $[42,268,269]$. In another study, a higher frequency of ICAM-1 expression was observed in $H$. pylori positive plaques [270]. Both periodontitis and C. pneumoniae have been known to increase the concentration of endothelial dysfunction markers in circulation [271,272,273]. Earlier studies have shown that $C$. pneumoniae infection is associated with increased expression of cell adhesion molecules [41,274,275].

Macrophage cholesterol disturbance, both influx and efflux is essential for atherogenesis. Inflammation alters HDL composition drastically [276-278]. Wang et al. [14] demonstrated that metabolism of phospholipid associated molecules by the gut bacteria promotes atherosclerosis [14]. They also observed that increased plasma TMAO levels in Apo-E deficient mice correlated positively with atheroma burden. Translocation of bacteria from the buccal cavity to circulation in CVDs occurs due to periodontal infections or because of dental procedures and tooth cleaning $[33,46,279]$. Infection in atherosclerosis may promote vessel wall injury initiated by oxidized lipids, smoking derived oxidants and hypertension or diabetic glycoxidized molecules. Macrophages and T-cells infiltrate atherosclerotic lesions and localize in the region where atheroma grows leading to more deposition of fibrous tissues in the lesions. Vascular SMCs synthesize the extracellular matrix responsible for plaque maturation [280]. Human atheromata express increased concentrations of IL-18 and its receptor subunits [281]. Plaque rupture and the following thrombotic conditions commonly cause the most dreaded acute complications of atherosclerosis.

Release of microbial components such as, LPS into the circulation involves indirect influence of microbes over the development and progression of atherosclerosis. MMP9 contributes to plaque rupture by dysregulation of the extracellular matrix during the complication of atherothrombosis [282]. Inflammation occurs during all stages of atherosclerosis from initiation of lesion to progression and destabilization. In addition, inflammation regulates both the solid state thrombotic potential of the plaque and the antifibrinolytic capacity of blood [283]. Aortic stiffness is positively correlated with circulating MMP-9 levels, suggesting its role in the development of systolic hypertension [284]. Patients with stable CAD have higher levels of MMP-9 than healthy individuals [285]. Serum MMP-9 levels are positively correlated with circulating LDL concentrations and negatively correlated with HDL concentrations [286]. Plasma MMP-9 levels were increased two to three fold compared to normal during acute coronary syndromes, indicating an active role of MMP-9 in plaque rupture $[287,288]$. Bacterial infections may precipitate an acute thrombus event on a vulnerable plaque; leading to acute MI. Microbial products in the circulation may cause thrombocytosis, platelet aggregation, increased fibrinogen and stimulation of proinflammatory cytokines [40,289].

Inflammation at nonvascular sites such as oral cavity can induce chronic inflammation within the arterial walls. Proinflammatory cytokines and other factors that are generated from the oral tract in oral diseases can be released into the circulation and taken up into the walls of arteries. Tooth loss has 
been associated with an increased risk of CAD and Stroke [290]. Another indirect mechanism is the formation of dysfunctional HDL because of inflammation [291]. Vascular cells also generate ROS in response to stress, which is seen in viral infections such as CMV. Deshpande et al. [1998] studied the invasion of bovine and human aortic endothelial cells by P. gingivalis [292]. Haraszthy et al. [2000] examined 50 human specimens obtained during carotid endarterectomy for the presence of $C$. pneumoniae, CMV and bacterial 16S rRNA using PCR assays [293]. Kuramitsu et al. [294] demonstrated that several properties in $P$. gingivalis could act as mediators of LDL oxidation, foam cell formation and atherosclerotic plaque rupture [294].

Earlier studies show that LPS from E. coli stimulate the expression of endothelial cell adhesion molecules and subsequent adherence of leukocytes to the endothelia $[295,296]$ and are the classical activators of cytokine production in atheroma [297,298]. Further, LPS are known to induce intravascular coagulation and lower HDL levels [299]. LPS levels may be influenced by the concentration of LPS transporters, antibodies, HDL, and other immunogenic, microbiological and physiological variables [300]. In the same study, it was also found that TLR- 4 and its adapter protein may play a role in the production of MMP-1 and 3 . HMGB1 is being released by the necrotic cells and macrophages or monocytes in response to external stimuli by bacterial LPS. HMGB1 elements have earlier been reported to be higher in atherosclerotic patients [301] and it has also been studied that endothelial cell activation leads to the release of HMGB1 elements [302]. HMGB1 is expressed in human atherosclerotic SMCs [303].

A number of key signaling pathways have been studied in atherosclerosis [304]. Expression of TLRs is found to be increased in diseased arteries compared to healthy vessels during atherogenesis [305]. TLRs have been studied as the main source of plaque activation in atherosclerosis lesions earlier [305]. Expression of TLRs has been best characterized in monocytes and dendritic cells. Recruitment of monocytes into atherosclerotic plaques occurs in proportional to plaque size [306]. Kaplan et al. [64] studied T-cell activation and senescence to predict carotid artery disease in HIV-infected patients [62]. Pattern recognition receptors (PRRs), which include Toll-like receptors (TLRs), RIG-1 like receptors (RLRs) and NOD-like receptors (NLRs), have been implicated in the initiation and progression of atherosclerosis $[307,308]$.

Bacteria invade the vascular tissue and localize themselves in the intracellular environment. The ability of a bacterium to invade tissues is an important virulence property since it provides a secure environment with access to the host proteins and substrates; protection from host's humoral and cellular immune response; and a means for persistence which is very essential for the survival of a pathogen. Injury to the vascular endothelium leads to the development of atherosclerosis, since it involves both the innate and adaptive immune systems. This inflammatory process leads to endothelial activation, release of growth factor, monocyte adhesion and migration while maturing into macrophages, followed by foam cell formation and proliferation of smooth muscle cells. Certain bacteria have also evolved to invade non-professional phagocytic cells. Successful bacterial invasion occurs in five stages viz., attachment, internalization, trafficking, persistence and exit out of the cell. Internalization of a bacterium also results in different cellular responses. Internalized bacteria can remain in a dormant state or multiply, resulting in persistent infection. Finally, intracellular bacteria exits out of the cell either by host cell lysis [309], or egresses by controlling the host cell process [310], or by both [311].

\section{Effect of circulating peptidoglycans on vascular endothelia}

NOD2 recognizes peptidoglycans of Gram positive bacteria and stimulates immune reaction. Oxidative damage to the intestine is exacerbated by the synthesis of cytokines, in particular, $\mathrm{TNF} \alpha$, ILs and NO [312]. TLR-2 expression is increased on circulating monocytes in atherosclerotic disease patients [313,314]. Earlier findings also suggest that TLR-2 may promote plaque vulnerability and rupture [315]. Circulating monocytes in mice with atherosclerosis have also been known to exhibit increased expression of TLR-2 and TLR-4 [43]

\section{Effect of circulating microbial nucleic acids on vascular endothelia}

Bacterial DNA in blood might include both viable and nonviable bacteria and may reflect clinical outcome due to the presence of bacterial products in blood. Ono et al. [316] studied 52 surgical patients for bacterial translocation by bacterial DNA detection in blood [316]. Bacterial DNA associated inflammatory response was found to be directly proportional to the serum concentrations of bacterial DNA, implying the role of bacterial DNA translocation in immune response [65,75]. Also, the binding of TLR-2, TLR-4 and TLR-9 on macrophages was found to promote lipid uptake and foam cell formation [149,307]. On the other hand, TLR-3 has been studied to protect the host from arterial injury and atherosclerosis. TLR-3 activation using the synthetic ligand poly (I: C) leads to decreased neointima formation in mice studies [66].

Viruses known to infect heart tissue include adenoviruses, Coxsackie viruses, Hepatitis A virus (HAV) and Herpes simplex viruses (HSV). Adenoviruses viruses are a major cause of acute respiratory infections, conjunctivitis and other illnesses. Marek's disease virus (MDV) has been recognized for some time as a causal agent of atherosclerosis in chickens [317]. In a study on 391 patients referred for chest pain or other evidence of myocardial ischemia, Zhu et al. [318] found that $52 \%$ of patients had IgG antibodies for HAV [318]. The actual prevalence of CAD was $74 \%$ in HAV seropositive patients and $52 \%$ in HAV seronegative patients $(P<0.0001)$. The association remained significant after controlling other cardiovascular risk factors and HAV might contribute to CAD by eliciting a chronic inflammatory response. HSV1 and 2 have been detected in human atherosclerotic plaques earlier. CMV, a member of the Herpes virus family, can infect individuals but does not cause any symptoms. Studies have shown both positive and negative associations of CMV with CAD.

\section{References}

1. WHO (2014) Global status report on noncommunicable diseases 298.

2. Drennan M (1942) What is 'Sterile Blood'? BMJ 2(4269): 526. 
3. Nikkari S, McLaughlin IJ, Bi W, Dodge DE, Relman DA (2001) Does blood of healthy subjects contain bacterial ribosomal DNA? J Clin Microbiol 39(5):1956-1959.

4. Li SK, Leung RK, Guo HX, Wei JF, Wang JH, Kwong KT et al. (2012) Detection and identification of plasma bacterial and viral elements in HIV/AIDS patients in comparison to healthy adults. Clin Microbiol Infect 18(11): 1126-1133.

5. Rajendhran J, Gunasekaran P ( 2010) Human microbiomics. Indian J Microbiol 50(1): 109-112.

6. Cho I, Blaser MJ (2012) The human microbiome: at the interface of health and disease. Nat Rev Genet 13(4): 260-270.

7. Yacoub AT, Monta R, Quaiser S, Acevedo I, Greene J (2015) Pneumococcal bacteremia in patients with cancer: a retrospective observational study, 2003-2013. Infect Dis Clin Pract 23(5): 263 266.

8. Bassetti S, Wasmer S, Hasler P, Vogt T, Nogarth D, et al. (2005) Staphylococcus aureus in patients with rheumatoid arthritis under conventional and anti-tumor necrosis factor-alpha treatment. J Rheumatol 32(11): 2125-2129.

9. Nolan JP (1981) Endotoxin, RES function and liver injury. Hepatol 1(5): 458-465

10. McIntyre CW, Harrison LEA, Eldehni MT, Jefferies HJ, Szeto CC, et al. (2011) Circulating endotoxemia: a novel factor in systemic inflammation and cardiovascular disease in chronic kidney disease. Clin J Am Soc Nephrol 6(1): 133-141.

11. Shinha T, Hadi C (2015) Clostridium paraputrificum bacteremia associated with colonic necrosis in a patient with AIDS. Case Rep Infect Dis.

12. Ott SJ, El Mokhtari NE, Musfeldt M, Hellmig S, Freitag S, et al. (2006) Detection of diverse bacterial signatures in atherosclerotic lesions of patients with coronary heart disease. Circ 113(7): 929-937.

13. Cotti E, Dessi C, Piras A, Flore G, Deidda M, et al. (2011) Association of endodontic infection with detection of an initial lesion to the cardiovascular system. J Endod 37(12): 1624-1629.

14. Wang Z, Klipfell E, Bennett BJ, Koeth R, Levison BS, et al. (2011) Gut flora metabolism of phosphatidylcholine promotes cardiovascular disease. Nature 472: 57-63.

15. Tang WHW, Wang Z, Levison BS, Koeth RA, Britt EB, et al. (2013) Intestinal microbial metabolism of phosphatidylcholine and cardiovascular risk. N Engl J Med 368(17): 1575-1584.

16. Koeth RA, Wang Z, Levison BS, Buffa JA, Org E, Sheehy BT, et al (2013) Intestinal microbiota metabolism of L-carnitine, a nutrient in red meat, promotes atherosclerosis. Nat Med 19(5): 576-585.

17. Senthong V, Li X, Coughlin J, Hudec T, Neale S, et al. (2015) Higher plasma trimethylamine-n-oxide is associated with greater atherosclerotic burden quantified by the syntax score. J Am Coll Cardiol 65(10): A1676.

18. Senthong V, Wang Z, Wu Y, Tang WH, Hazen SL (2015) a Elevated plasma trimethylamine-n-oxide is associated with poor prognosis in patients with peripheral artery disease. J Am Coll Cardiol 65(10): A2076.

19. Pussinen PJ, Nyyssonen K, Alfthan G, Salonen R, Laukkanen JA, et al. (2005) Serum antibody levels to Actinobacillus actinomycetemcomitans predict the risk for coronary heart disease. Arterioscler Thromb Vasc Biol 25(4): 833-838.
20. Konter JM, Parker JL, Baez E, Li SZ, Ranscht B, Denzel M, et al. (2012) Adiponectin attenuates lipopolysaccharide-induced acute lung injury through suppression of endothelial cell activation. J Immunol 188(2): 854-863.

21. Orman MA, Brynildsen MP (2013) Dormancy is not necessary or sufficient for bacterial persistence. Antimicrob Agents Chemother 57(7): 3230-3239.

22. Lleo MM, Ghidini V, Tafi MC, Castellani F, Trento I, et al. (2014) Detecting the presence of bacterial DNA by PCR can be useful in diagnosing culture-negative cases of infection, especially in patients with suspected infection and antibiotic therapy. FEMS Microbiol Lett 354(2): 153-160.

23. Amar J, Serino M, Lange C, Chabo C, Iacovoni J, et al. (2011) Involvement of tissue bacteria in the onset of diabetes in humans: evidence for a concept. Diabetologia 54(12): 3055-3061.

24. Amar J, Lange C, Payros G, Garret C, Chabo C, et al. (2013) Blood microbiota dysbiosis is associated with the onset of cardiovascular events in a large general population: The D.E.S.I.R. study. PLoS One 8(1): e54461.

25. Rajendhran J, Shankar M, Dinakaran V, Rathinavel A, Gunasekaran $P$ (2013) Contrasting circulating microbiome in cardiovascular disease patients and healthy individuals. Inter J Cardiol 168(5): 5118-5120.

26. Dinakaran V, Rathinavel A, Pushpanathan M, Sivakumar R, Gunasekaran P, et al. (2014) Elevated levels of circulating DNA in cardiovascular disease patients: metagenomic profiling of microbiome in the circulation. PLoS One 9(8): e105221.

27. Lluch J, Servant F, Paisse S, Valle C, Valiere S, et al. (2015) The characterization of novel tissue microbiota using an optimized $16 \mathrm{~S}$ metagenomic sequencing pipeline. PLoS One 10(11): e0142334.

28. Li L, Deng X, Linsuwanon P, Bangsberg D, Bwana MB, et al. (2013) AIDS alters the commensal plasma virome. J Virol 87(19): 1091210915.

29. Alexander JW, Boyce ST, Babcock GF, Gianotti L, Peck MD, et al (1990) The process of microbial translocation. Ann Surg 212(4): 496-512.

30. Silver JG, Martin AW, McBride BC (1977) Experimental transient bacteraemias in human subjects with varying degrees of plaque accumulation and gingival inflammation. J Clin Periodontol 4(2): 92-99.

31. Geerts SO, Nys M, Mol PDe, Charpentier J, Albert A, et al. (2002) Systemic release of endotoxins induced by gentle mastication: association with periodontitis severity. J Periodontol 73(1): 73-78.

32. Guntheroth WG (1984) How important are dental procedures as a cause of infective endocarditis? Am J Cardiol 54(7): 797-801.

33. Rajasuo A, Perkki K, Nyfors S, Jousimies-Somer H, Meurman JH (2004) Bacteremia following surgical dental extraction with an emphasis on anaerobic strains. J Dent Res 83(2): 170-174.

34. Wiedermann CJ, Kiechl S, Dunzendorfer S, Schratzberger P, Egger G, et al. (1999) Association of endotoxemia with carotid atherosclerosis and cardiovascular disease. Prospective results from the Bruneck study. J Am Coll Cardiol 34(7): 1975-1981.

35. Pussinen PJ, Vilkuna-Rautiainen T, Alfthan G, Palosuo T, Jauhiainen $M$, et al. (2004) Severe periodontitis enhances macrophage activation via increased serum lipopolysaccharide. Arterioscler Thromb Vasc Biol 24(11): 2174-2180. 
36. Pussinen PJ, Tuomisto K, Jousilahti P, Havulinna AS, Sundvall J, et al. (2007) Endotoxemia, immune response to periodontal pathogens, and systemic inflammation associate with incident cardiovascular disease events. Arterioscler Thromb Vasc Biol 27(6): 1433-1439.

37. Krack A, Sharma R, Figulla HR, Anker SD (2005) The importance of gastrointestinal system in the pathogenesis of heart failure. Eur Heart J 26(22): 2368-2374.

38. Sconyers JR, Crawford JJ, Moriarty JD (1973) Relationship of bacteremia to tooth brushing in patients with Periodontitis. J Am dental Assoc 87(3): 616-622.

39. Renko J, Lepp PW, Oksala N, Nikkari S, Nikkar ST (2008) Bacterial signatures in atherosclerotic lesions represent human commensals and pathogens. Atheroscler 201(1): 192-197.

40. Etingin OR, Silverstein RL, Friedman HM, Hajjar DP (1990) Viral activation of the coagulation cascade: molecular interactions at the surface of infected endothelial cells. Cell 61(4): 657-662.

41. Liuba P, Pesonen E, Paakkari I, Batra S, Forslid A, et al. (2003) Acute Chlamydia pneumoniae infection causes coronary endothelial dysfunction in pigs. Atheroscler 167(2): 215-222.

42. Wellicome SM, Thornhill MH, Pitzalis C, Thomas DS, Lanchbury JS et al. (1990) A monoclonal antibody that detects a novel antigen on endothelial cells that is induced by tumor necrosis factor, IL-1, or lipopolysaccharide. J Immunol 144(7): 2558-2565.

43. Schoneveld AH, Hoefer I, Sluijtera JPG, Laman JD, de Kleijna DPV, et al. (2008) Atherosclerotic lesion development and Toll-like receptor 2 and 4 responsiveness. Atheroscler 197(1): 95-104.

44. Clarke TB, Davis KM, Lysenko ES, Zhou AY, Yu Y, et al. (2010) Recognition of peptidoglycan from the microbiota by Nod1 enhances systemic innate immunity. Nat Med 16(2): 228-231.

45. Mann DL (2011) The emerging role of innate immunity in the heart and vascular system. For whom the cell tolls. Circ Res 108(9): 11331145.

46. Forner L, Larsen T, Kilian M, Holmstrup P (2006) Incidence of bacteremia after chewing, tooth brushing and scaling in individuals with periodontal inflammation. J Clin Periodontol 33(6): 401-407.

47. Sedman PC, Macfie J, Sagar P, Mitchell CJ, May J, et al. (1994) The prevalence of gut translocation in humans. Gastroenterol 107(3): 643-639.

48. Balzan S, De Almeida Quadros C, De Cleva R, Zilberstein B, Cecconello I (2007) Bacterial translocation: Overview of mechanisms and clinical impact. J Gastroenterol Hepatol 22(4): 464-471.

49. van Leeuwen PAM, Hong RW, Rounds JD, Rodrick M, Wilmore DW (1991) Hepatic failure and coma after liver resection is reversed by manipulation of gut contents: the role of endotoxin. Surg 110(2): 169-175.

50. Oudemans-van Straaten HM, Jansen PG, te Velthuis H, Beenakkers IC, et al. (1996) Increased oxygen consumption after cardiac surgery is associated with the inflammatory response to endotoxemia. Intensive Care Med 22(4): 294-300.

51. Szeto CC, Kwan BC, Chow KM, Lai KB, Chung KY, et al. (2008) Endotoxemia is related to systemic inflammation and atherosclerosis in peritoneal dialysis patients. Clin J Am Soc Nephrol 3(2): 431-436.

52. Krzych L, Wybraniec M, Chudek J, Bochenek A (2013) Perioperative management of cardiac surgery patients who are at the risk of acute kidney injury. Anaesthesiol Intensive Ther 45(3): 155-163.
53. Niebauer J, Volk HD, Kemp M, Dominguez M, Schumann RR, et al. (1999) Endotoxin and immune activation in chronic heart failure: a prospective cohort study. Lancet 353(29): 1838-1842.

54. Frances R, Casellas JA, Benlloch S, Uceda F, Zapater P, et al. (2004) A sequential study of serum bacterial DNA in patients with advanced cirrhosis and ascites. Hepatol 39(2): 484-491.

55. Abdeldayem H, Ghoneim E, Ahmad-El Refaei A, Abou-Gabal A (2007) Obstructive jaundice promotes intestinal barrier dysfunction and bacterial translocation: experimental study. Hepatol Int 1(4): 444448.

56. Pearce CB, Zinkevich V, Beech I, Funjika V, Ruiz AG, et al. (2005) Using the polymerase chain reaction coupled with denaturing gradient gel electrophoresis to investigate the association between bacterial translocation and systemic inflammatory response syndrome in predicted acute severe pancreatitis. World J Gastroenterol 11(45): 7142-7147.

57. Slots J, Nowzari H, Sabeti M (2004) Cytomegalovirus infection in symptomatic periapical pathosis. Int Endod J 37(8): 519-524.

58. Joshipura KJ, Pitiphat W, Hung HC, Willett WC, Colditz GA, Douglass CW (2006) Pulpal inflammation and incidence of coronary heart disease. J Endodont 32(2): 99-103.

59. Srinivasa S, Fitch KV, Lo J, Kadar H, Knight R, et al. (2015) Plaque burden in HIV-infected patients is associated with serum intestinal microbiota-generated trimethylamine. AIDS 29(4): 443-452.

60. Sato J, Ikeda F, Kanazawa A, Yoshihara T, Goto H, et al. (2014) Gut dysbiosis and detection of "live gut bacteria" in blood of Japanese patients with type 2 diabetes. Diabetes Care 37(8): 2343-2350.

61. Toossi Z, Funderburg NT, Sirdeshmuk S, Whalen CC, Nanteza MW, et al. (2013) Systemic immune activation and microbial translocation in dual HIV/tuberculosis-infected subjects. J Infect Dis 207(12): 1841-1849.

62. Kaplan RC, Sinclair E, Landay AL, Lurain N, Sharrett AR, et al. (2011) T-cell activation and senescence predict subclinical carotid artery disease in HIV-infected women. J Infect Dis 203(4): 452-463.

63. Manner IW, Baekken M, Kvale D, Oektedalen O, Pedersen M, et al. (2013) Markers of microbial translocation predict hypertension in HIV-infected individuals. HIV Med 14(6): 354-361.

64. Smith PD, Smythies LE, Mosteller-Barnum M, Sibley DA, Russell MW, et al. (2001) Intestinal macrophages lack CD14 and CD89 and consequently are down-regulated for LPS- and IgA mediated activities. J Immunol 167(5): 2651-2656.

65. Jiang W, Lederman MM, Hunt P, Sieg SF, Haley K, et al. (2009) Plasma levels of bacterial DNA correlate with immune activation and the magnitude of immune restoration in persons with antiretroviraltreated HIV infection. J Infect Dis 199(8): 1177-1185.

66. Cole JE, Navin TJ, Cross AJ, Goddard ME, Alexopoulou L, et al. (2011) Unexpected protective role for Toll-like receptor 3 in the arterial wall. Proc Natl Acad Sci USA 108(6): 2372-2377.

67. Sundqvist G (1992) Ecology of the root canal flora. J Endod 18(9): 427-430.

68. Gomes BP, Lilley JD, Drucker DB (1996) Clinical significance of dental root canal microflora. J Dent 24(1-2): 47-55.

69. Wagner DR, McTiernan C,Sanders VJ, Feldman AM (1998) Adenosine inhibits lipopolysaccharide-induced secretion of tumor necrosis factor-alpha in the failing human heart. Circ 97(6): 521-524. 
70. Morell GP, Pirotzky E, Erard D, Desmottes RM, Bidault J, et al. (1988) Paf-acether (platelet-activating factor) and interleukin-1-like cytokine production by lipopolysaccharide-stimulated glomeruli. Clin Immunol Immunopathol 46(3): 396-405.

71. Dai G, Kaazempur-Mofrad MR, Natarajan S, Zhang Y, Vaughn S, et al. (2004) Distinct endothelial phenotypes evoked by arterial waveforms derived from atherosclerosis susceptible and resistant regions of human vasculature. Proc Natl Acad Sci USA 101(41): 14871-14876.

72. Yla-Herttuala S, Palinski W, Rosenfeld ME, Parthasarathy S, Carew TE, et al. (1989) Evidence for the presence of oxidatively modified low density lipoprotein in atherosclerotic lesions of rabbit and man. J Clin Invest 84(4): 1086-1095.

73. Willershausen B, Kasaj A, Willershausen I, Zahorka D, Briseno B, et al. (2009) Association between chronic dental infection and acute myocardial infarction. J Endodont 35(5): 626-630.

74. Summersgill JT, Molestina RE, Miller RD, Ramirez JA (2000) Interactions of Chlamydia pneumoniae with human endothelial cells. J Infect Dis 181(3): S479-S482.

75. Rutz M, Metzger J, Gellert T, Luppa P, Lipford GB, et al. (2004) Tolllike receptor 9 binds single-stranded CpG-DNA in a sequence and pH-dependent manner. Eur J Immunol 34(9): 2541-2550.

76. Beck JD, Pankow J, Tyroler HA, Offenbacher S (1999) Dental infections and atherosclerosis. Am Heart J 138(5Pt2): 528-533.

77. Herzberg MC, Meyer MW (1996) Effects of oral flora on platelets: possible consequences in cardiovascular disease. J Periodontol 67(10): 1138-1142.

78. Warwick S, Wilks M, Hennessy E, Powell-Tuck J, Small M, et al. (2004) Use of quantitative $16 \mathrm{~S}$ ribosomal DNA detection for diagnosis of central venous catheter associated biomaterial infection. J Clin Microbiol 42(4): 1402-1408.

79. Mills J, Drew D (1976) Serratia marcescens endocarditis: a regiona illness associated with intravenous drug abuse. Ann Intern Med 84(1): 29-35.

80. Baddour LM, Bettmann MA, Bolger AF, Epstein AE, Ferrieri P, et al (2003) Nonvalvular cardiovascular device-related infections. Circ 108(16): 2015-2031.

81. Brooks RG, Hofflin JM, Jamieson SW, Stinson EB, Remington JS (1985) Infectious complications in heart-lung transplant recipients. Am J Med 79(4): 412-422.

82. McLaughlin RW, Vali H, Lau PCK, Palfree RGE, De Ciccio A, et al. (2002) Are there naturally occurring pleomorphic bacteria in the blood of healthy humans? J Clin Microbiol 40(12): 4771-4775.

83. Proal AD, Albert PJ, Marshall TG (2014) Inflammatory disease and the human microbiome. Discov Med 17(95): 257-265.

84. Tedeschi GG, Amici D, Paparelli M (1969) Incorporation of nucleosides and amino-acids in human erythrocyte suspensions: possible relation with a diffuse infection of mycoplasmas or bacteria in the L form. Nature 222(5200): 1285-1286.

85. Markova N, Slavchev G, Michailova L (2015) Presence of mycobacterial L-forms in human blood: challenge of BCG vaccination. Hum Vaccin Immunother 11(5): 1192-1200.

86. Domingue GJ, Schlegel JU (1977) Novel bacterial structures in human blood: cultural isolation. Infect Immun 15(2):621-627.
87. Tedeschi GG, Bondi A, Paparelli M, Sprovieri G (1978) Electron microscopical evidence of the evolution of Corynebacteria-like microorganisms within human erythrocytes. Experientia 34(4): 458-460.

88. Moriyama K, Ando C, Tashiro K, Kuhara S, Okamura S, et al. (2008) Polymerase chain reaction detection of bacterial $16 \mathrm{~S}$ rRNA gene in human blood. Microbiol Immunol 52(7): 375-382.

89. Popgeorgiev N, Boyer M, Fancello L, Monteil S, Robert C, et al. (2013) Marseillevirus-like virus recovered from blood donated by asymptomatic humans. J Infect Dis 208(7): 1042-1050.

90. Popgeorgiev N, Boyer M, Fancello L, Monteil S, Robert C, et al. (2013) Marseillevirus-like virus recovered from blood donated by asymptomatic humans. J Infect Dis 208(7): 1042-1050.

91. Bigger JW (1944) Treatment of Staphylococcal infections with penicillin by intermittent sterilization. Lancet 244: 497-500.

92. O’Boyle CJ, MacFie J, Mitchell CJ, Johnstone D, Sagar PM, et al. (1998) Microbiology of bacterial translocation in humans. Gut 42(1): 2935 .

93. Kaprelyants AS, Gottschal JC, Kell DB (1993) Dormancy in nonsporulating bacteria. FEMS Microbiol Rev 10(3-4): 271-285.

94. Epstein SS (2013) The phenomenon of microbial uncultivability. Curr Opin Microbiol 16(5): 636-642.

95. LaFleur MD, Qi Q Lewis K (2010) Patients with long-term oral carriage harbor high-persister mutants of Candida albicans. Antimicrob Agents Chemother 54(1): 39-44.

96. Mulcahy LR, Burns JL, Lory S, Lewis K (2010) Emergence of Pseudomonas aeruginosa strains producing high levels of persister cells in patients with cystic fibrosis. J Bacteriol 192(23): 6191-6199.

97. Nerheim PL, Meier JL, Vasef MA, Li WG, Hu L, et al. (2004) Enhanced Cytomegalovirus infection in atherosclerotic human blood vessels. Am J Pathol 164(2): 589-600.

98. Gorski A, Wazna E, Browska BD, Dabrowska K, Switala-Jelen K (2006) Bacteriophage translocation. FEMS Immunol Med Microbiol 46(3): 313-319.

99. Lasken RS, McLean JS (2014) Recent advances in genomic DNA sequencing of microbial species from single cells. Nat Rev Genet 15(9): 577-584

100. Goto T, Eden S, Nordenstam G, Sundh V, Svanborg-Eden C, et al. (1994) Endotoxin levels in sera of elderly individuals. Clin Diag Lab Immun0l 1(6): 684-688.

101. Domingue GJ (2010) Demystifying pleomorphic forms in persistence and expression of disease: are they bacteria, and is peptidoglycan the solution? Discov Med 10(52): 234-246.

102. Rainer TH, Wong LKS, Lam W, Yuen E, Lam NY, et al. (2003) Prognostic use of circulating plasma nucleic acid concentrations in patients with acute stroke. Clin Chem 49(4): 562-569.

103. Tan EM, Schur PH, Carr RI, Kunkel HG (1966) Deoxyribonucleic acid (DNA) and antibodies to DNA in the serum of patients with systemic lupus erythematosus. J Clin Invest 45(11): 1732-1740.

104. Satpathy G, Bhan A, Sharma A, Kar UK (2008) Detection of Chlamydophila pneumoniae (Chlamydia pneumoniae) in endarteroctomy specimens of coronary heart diseases patients. Indian J Med Res 128(5): 658-662. 
105. Fukuda Y, Momoi N, Akaihata M, Nagasawa K, Mitomo M, et al. (2015) Pulmonary arterial hypertension associated with chronic active Epstein-Barr virus infection. Pediatr Inter 57(4):731-734.

106. Wang M, Lin J, Sun S, Yuan X (2015) Identification of Granulicatella elegans from a case of infective endocarditis, based on the phenotypic characteristics and 16S rRNA gene sequence. J Cardiovasc Med (Hagerstown) 16(2): S138-S140.

107. Stollberger C, Finsterer J (2002) Role of infectious and immune factors in coronary and cerebrovascular arteriosclerosis. Clin Diagn Lab Immunol 9(2): 207-215.

108. Abbas M, Bignamini V, Corea F (2006) Effects of chronic microbial infection on atherosclerosis. Atheroscler 187: 439-440.

109. Espinola-Klein C, Rupprecht HJ, Blankenberg S, Bickel C, Kopp H, et al. (2002) Impact of infectious burden on extent and long-term prognosis of atherosclerosis. Circ 105(1): 15-21.

110. Niedzielska I, Janic T, Cierpka S, Swietochowska E (2008) The effect of chronic periodontitis on the development of atherosclerosis: review of the literature. Med Sci Monit 14(7): 103-106.

111. Toss H, Gnarpe J, Gnarpe H, Siegbahn A, Lindahl B, et al. (1998) Increased fibrinogen levels are associated with persistent Chlamydia pneumoniae infection in unstable coronary artery disease. Eur Heart J 19(4): 570-577.

112. Guan SM, Shu L, Fu SM, Liu B, Xu XL, et al. (2009) Prevotella intermedia upregulates MMP-1 and MMP-8 expression in human periodontal ligament cells. FEMS Microbiol Lett 299: 214-222.

113. Chiu B, Viira E, Tucker W, Fong IW (1997) Chlamydia pneumoniae, Cytomegalovirus, and herpes simplex virus in atherosclerosis of the carotid artery. Circ 96: 2144-2148.

114. Kuo CC, Gown AM, Benditt EP, Grayston JT (1993) Detection of Chlamydia pneumoniae in aortic lesions of atherosclerosis by immunocytochemical stain. Arterioscler Thromb Vasc Biol 13: 1501-1504.

115. Kalayoglu MV, Libby P, Byrne GI (2002) Chlamydia pneumoniae as an emerging risk factor in cardiovascular disease. JAMA 288(21): 2724-2731.

116. Scannapieco FA, Bush RB, Paju S (2003) Associations between periodontal disease and risk for atherosclerosis, cardiovascular disease and stroke. A systematic review. Ann Periodontol 8(1): 3853.

117. McGillicuddy FC, de la L Moya M, Hinkle CC, Joshi MR, Chiquoine EH, et al. (2009) Inflammation impairs reverse cholesterol transport in vivo. Circ 119(8): 1135-1145.

118. Rajamaki K, Lappalainen J, Oorni K, Valimaki E, Matikainen S, et al. (2010) Cholesterol crystals activate the NLRP3 inflammasome in human macrophages: a novel link between cholesterol metabolism and inflammation. PLoS One 5(7): e11765.

119. Duewell P, Kono H, Rayner KJ, Sirois CM, Vladimer G, et al. (2010) NLRP3 inflammasomes are required for atherogenesis and activated by cholesterol crystals. Nature 464: 1357-1361.

120. Li W, Sama AE, Wang H (2006) Role of HMGB1 in cardiovascular diseases. Curr Opin Pharmacol 6(2): 130-135.

121. Chi F, Jong TD, Wang L, Ouyang Y, Wu C, et al. (2010) Vimentinmediated signalling is required for IbeA E. coli K1 invasion of human brain microvascular endothelial cells. Biochem J 427: 79-90.
122. Monack DM, Mueller A, Falkow S (2004) Persistent bacterial infections: the interface of the pathogen and the host immune system. Nat Rev Microbiol 2(9): 747-765.

123. Li L, Michel R, Cohen J, DeCarlo A, Kozarov E (2008) Intracellular survival and vascular cell-to-cell transmission of Porphyromonas gingivalis. BMC Microbiol 8: 26-36.

124. Tew JG, El Shikh ME, El Sayed RM, Schenkein HA (2011) Dendritic cells, antibodies reactive with oxLDL, and inflammation. J Dent Res 91(1): 8-16.

125. Sato Y, Kishi J, Suzuki K, Nakamura H, Hayakawa T ( 2009) Sonic extracts from a bacterium related to periapical disease activate gelatinase $\mathrm{A}$ and inactivate tissue inhibitor of metalloproteinases TIMP-1 and TIMP-2. Int Endodont J 42(12):1104-1111.

126. Hajishengallis G, Martin M, Schifferle RE, Genco RJ (2002) Counteracting interactions between lipopolysaccharide molecules with differential activation of Toll-like receptors. Infect Immun 70(12): 6658-6664

127. Beck JD, Offenbacher S (2005) Systemic effects of periodontitis: epidemiology of periodontal disease and cardiovascular disease. J Periodontol 76(11 Suppl): 2089-2100.

128. Beck JD, Elter JR, Heiss G, Couper D, Mauriello SM, et al. (2001) Relationship of periodontal disease to carotid artery intima-media wall thickness: the atherosclerosis risk in communities (ARIC) study. Arterioscler Thromb Vasc Biol 21: 1816-1822

129. Pussinen PJ, Jousilahti P, Alfthan G, Palosuo T, Asikainen S, et al (2003) Antibodies to periodontal pathogens are associated with coronary heart disease. Arterioscler Thromb Vasc Biol 23(7): 12501254.

130. Kozarov (2012) Bacterial invasion of vascular cell types: vascular infectology and atherogenesis. Future Cardiol 8(1): 123-138.

131. Epstein SE, Zhu J, Najafi AH, Burnett MS (2009) Insights into the role of infection in atherogenesis and in plaque rupture. Circ 119(24): 3133-3141.

132. Vita JA, Loscalzo J (2002) Shouldering the risk factor burden. Infection, atherosclerosis, and the vascular endothelium. Circ 106(2): 164-166

133. Pataki M, Lusztig G, Robenek H (1992) Endocytosis of oxidized LDL and reversibility of migration inhibition in macrophage-derived foam cells in vitro. A mechanism for atherosclerosis regression? Arterioscler Thromb 12(8): 936-944.

134. Sowers JR, Lester MA (1999) Diabetes and cardiovascular disease. Diabetes Care, suppl. Therapeutic Approaches to Type 2 Diabetes: Proceedings from 22 (Apr 1999): C14-C20.

135. Holvoet P, Mertens A, Verhamme P, Bogaerts K, Beyens G, et al. (2001) Diabetes and cardiovascular disease. Diabetes Care, suppl. Therapeutic Approaches to Type 2 Diabetes: Proceedings from 22 21: 844-848.

136. Cominacini L, Garbin U, Pasinia AF, Davoli A, Campagnola M, et al. (1997) Antioxidants inhibit the expression of intercellular cell adhesion molecule- 1 and vascular cell adhesion molecule- 1 induced by oxidized LDL on human umbilical vein endothelial cells. Free Rad Biol Med 22(1-2): 117-127.

137. Frostegard J, Haegerstrand A, Gidlund M, Nilsson J. (1991) Biologically modified LDL increases the adhesive properties of endothelial cells. Atheroscler 90(2-3): 119-126. 
138. Wyplosz B, Montalescot G, Subtil A, Dujeancourt A, Tanguy ML, et al. (2006) Correlation between Chlamydia pneumonia detection from coronary angioplasty balloons and atherosclerosis severity. J Am Coll Cardiol 47: 1239-1240.

139. Melnick JL, Hu C, Burek J, Adam E, Debakey ME (1994) Cytomegalovirus DNA in arterial walls of patients with atherosclerosis. J Med Virol 42(2): 170-174.

140. Ishizaka N, Ishizaka Y, Takahashi E, Tooda E, Hashimoto H, et al (2002) Association between hepatitis $C$ virus seropositivity, carotidartery plaque, and intima-media thickening. Lancet 359(9301): 133-135.

141. Fabricant CG, Hajjar DP, Minick CR, Fabricant J (1981) Herpesvirus infection enhances cholesterol and cholesteryl ester accumulation in cultured arterial smooth muscle cells. Am J Pathol 105(2): 176184.

142. Nakano K, Inaba $H$, Nomura R, Nemoto $H$, Takeda M, et al. (2006) Detection of cariogenic Streptococcus mutans in extirpated heart valve and atheromatous plaque specimens. J Clin Microbiol 44(9) 3313-3317

143. Koren O, Spor A, Felin J, Fak F, Stombaugh J, et al. (2011) Human oral, gut, and plaque microbiota in patients with atherosclerosis. Proc Natl Acad Sci USA 108(Suppl 1): 4592-4598.

144. Zhang YM, Zhong LJ, Liang P, Liu H, Mu LT, et al. (2008) Relationship between microorganisms in coronary atheromatous plaques and periodontal pathogenic bacteria. Chin Med J 121(16): 1595-1597.

145. Gaetti-Jardim E, Marcelino SL, Feitosa ACR, Romito GA, AvilaCampos MJ, et al. (2009) Quantitative detection of periodontopathic bacteria in atherosclerotic plaques from coronary arteries. J Med Microbiol 58(pt 12): 1568-1575.

146. Reyes L, Herrera D, Kozarov E, Roldán S, Progulske-Fox A (2013) Periodontal bacterial invasion and infection: contribution to atherosclerotic pathology. J Clin Periodontol 40(Suppl 14): S30-S50.

147. Oiknine J, Aviram M (1992) Increased susceptibility to activation and increased uptake of low density lipoprotein by cholesterol loaded macrophages. Arterioscler Thromb Vasc Biol 12: 745-753.

148. Hegele RA (1996) The pathogenesis of atherosclerosis. Clin Chim Acta 246: 21-38.

149. Popovic M, Smiljanic K, Dobutovic B, Syrovets T, Simmet T, Isenovic ER (2012) Human cytomegalovirus infection and atherothrombosis. J Thromb Thrombol 33(2): 160-172.

150. Muller WA (2003) Leukocyte-endothelial cell interactions in leukocyte transmigration and inflammatory response. Trend Immunol 24(6): 326-333.

151. Puolakkainen M, Kuo CC, Shor A, Wang SP, Grayston JT, et al. (1993) Serological response to Chlamydia pneumoniae in adults with coronary arterial fatty streaks and fibrolipid plaques. J Clin Microbiol 31: 2212-2214.

152. West SK, Kohlhepp SJ, Jin R, Gleaves CA, Stamm W, et al. (2009) Detection of circulating Chlamydophila pneumoniae in patients with coronary artery disease and healthy control subjects. Clin Infect Dis 48: 560-567.

153. Hyvärinen K, Tuomainen AM, Laitinen S, Bykov IL, Törmäkangas L, et al. (2009) Chlamydial and periodontal pathogens induce hepatic inflammation and fatty acid imbalance in apolipoprotein E-deficient mice. Infect Immun 77: 3442-3449.
154. Goyal P, Kale SC, Chaudhry R, Chauhan S, Shah N (2007) Association of common chronic infections with coronary artery disease in patients without any conventional risk factors. Indian J Med Res 125(2): 129-136.

155. Ishihara K, Nabuchi A, Ito R, Miyachi K, Kuramitsu HK, et al. (2004) Correlation between detection rates of periodontopathic bacterial DNA in carotid coronary stenotic artery plaque and in dental plaque samples. J Clin Microbiol 42(3): 1313-1315.

156. Dorn BR, Dunn Jr WA, Progulske-Fox A (1999) Invasion of human coronary artery cells by periodontal pathogens. Infect Immun 67(11): 5792-5798.

157. Momiyama $\mathrm{Y}$, Ohmori $\mathrm{R}$, Taniguchi $\mathrm{H}$, Nakamura $\mathrm{H}$, Ohsuzu $\mathrm{F}$, et al. (2004) Association of Mycoplasma pneumoniae infection with coronary artery disease and its interaction with chlamydial infection. Atheroscler 176(1): 139-144.

158. Danesh J, Youngman L, Clark S, Parish S, Peto R, et al. (1999) Helicobacter pylori infection and early onset myocardial infarction: case-control and sibling pairs study. BMJ 319(7218): 1157-1162.

159. McDonald K, Rector TS, Braunlin EA, Kubo SH, Olivari MT (1989) Association of coronary artery disease in cardiac transplant recipients with cytomegalovirus infection. Am J Cardiol 64(5): 359362.

160. Vassalle C, Masini S, Bianchi F, Zucchelli GC (2004) Evidence for association between hepatitis $C$ virus seropositivity and coronary artery disease. Heart 90(5): 565-566.

161. Keane JF, Driscoll DJ, Gersony WM, Hayes CJ, Kidd L, et al. (1993) Second natural history study of congenital heart defects. Results of treatment of patients with aortic valvar stenosi. Circ 87(2 Suppl): 116-I27.

162. Stewart BF, Siscovick D, Lind BK, Gardin JM, Gottdiener IS, et al (1997) Clinical factors associated with calcific aortic valve disease. J Am Coll Cardiol 29(3): 630-634

163. Smeesters PR, Dreze PA, Perez-Morga D, Biarent D, Melderen LV, et al. (2010) Group A Streptococcus virulence and host factors in two toddlers with rheumatic fever following toxic shock syndrome. Int J Infect Dis 14(5): e403-e409.

164. Cunningham MW, Antone SM, Smart M, Liu R, Kosanke S, et al (1997) Molecular analysis of human cardiac myosin-cross-reactive B- and T-cell epitopes of the group A Streptococcal M5 protein. Infect Immun 65(9): 3913-3923.

165. Guilherme L, Oshiro SE, Fae KC, Cunha-Neto E, Renesto G, et al (2001) T-cell reactivity against Streptococcal antigens in the periphery mirrors reactivity of heart-infiltrating $\mathrm{T}$ lymphocytes in rheumatic heart disease patients. Infect Immun 69(9): 5345-5351.

166. Durack DT, Beeson PB (1972) Experimental bacterial endocarditis. II. Survival of bacteria in endocardial vegetations. Br J Exp Pathol 53(1): 50-53.

167. Gould K, Ramirez-Ronda CH, Holmes RK, Sanford JP (1975) Adherence of bacteria to heart valves in vitro. J Clin Invest 56(6): 1364-1370.

168. Crawford I, Russell C (1986) Comparative adhesion of seven species of streptococci isolated from the blood of patients with subacute bacterial endocarditis to fibrin-platelet clots in vitro. J Appl Bacteriol 60(2): 127-133.

169. Dobbins WO (1982) Gut immunophysiology: a gastroenterologist's view with emphasis on pathophysiology. Am J Phys 242: G1-G8. 
170. Berg RD, Garlington AW (1980) Translocation of Escherichia coli from the gastrointestinal tract to the mesenteric lymph nodes in gnotobiotic mice receiving Escherichia coli vaccines before colonization. Infect Immun 30(3): 894-898.

171. Berg RD (1981) Promotion of the translocation of enteric bacteria from the gastrointestinal tracts of mice by oral treatment with penicillin, clindamycin, or metronidazole. Infect Immun 33(3): 854861.

172. Mathison JC, Ulevitch RJ (1979) The clearance, tissue distribution and cellular localization of intravenously injected lipopolysaccharide in rabbits. J Immunol 123(5): 2133-2143.

173. Ruitter DJ, Van der Meulen J, Brouwer A, Hummel MJ, Miauw J, et al. (1981) Uptake by liver cells of endotoxin following it intravenous injection. Lab Invest 45(1): 38-45.

174. Van Leeuwen PAM, Boermeester MA, Houdijk APJ, Ferwerda Ch C Cuesta MA, et al. (1994) Clinical significance of translocation. 35(1 Suppl): S28-S34.

175. Clark MA, Jepson MA (2003) Intestinal M cells and their role in bacterial infection. Int J Med Microbiol 293(1): 17-39.

176. Kerneis S, Bogdanova A, Kraehenbuhl JP, Pringault E (1997) Conversion by Peyer's patch lymphocytes of human enterocytes into M cells that transport bacteria. Science 277(5328): 949-952.

177. Wells CI (1990) Relationship between intestinal microecology and the translocation of intestinal bacteria. Antonie van Leeuwenhoek 58(2): 87-93.

178. Troseid M, Ueland T, Hov JR, Svardal A, Gregersen I, et al. (2015) Microbiota-dependent metabolite trimethylamine-N-oxide is associated with disease severity and survival of patients with chronic heart failure. J Intern Med 277(6): 717-726.

179. Berg RD (1980) Mechanisms confining indigenous bacteria to the gastrointestinal tract. Amer J Clin Nutr 33(11 Suppl): 2472-2484.

180. MacFie J (1997) Bacterial translocation in surgical patients. Ann R Coll Surg Engl 79(3): 183-189.

181. Maier RV, Hahnel GB (1984) Microthrombosis during endotoxemia: the role of hepatic versus alveolar macrophages. J Surg Res 36(4): 362-370.

182. Coalson JJ, Archer LT, Hall NK, Kern JD, Benjamin BA, et al. (1979) Prolonged shock in the monkey following live E. coli organism infusion. Circ Shock 6(4): 343-355.

183. Van Deventer SJH, Gate JWT, Buller HR, Sturk A, Pauw W, et al. (1988) Endotoxemia: an early predictor of septicaemia in febrile patients. The Lancet 8586: 605-609.

184. Ford EG, Baisden CE, Matteson ML, Picone AL. (1991) Sepsis after coronary bypass grafting: evidence for loss of the gut mucosal barrier. Ann Thorac Surg 52(3): 514-517.

185. Schoffel U, Shiga J, Mittermayer Ch (1982) The proliferation inhibiting effect of endotoxin on human endothelial cells in culture and its possible implication in states of shock. Circ Shock 9(5): 499508.

186. Bernstein J, Brown AH (1962) Sepsis and jaundice in early infancy. Pediatrics 29: 873-882.

187. Thorne SA, Hooper J, Kemp M, Somerville J (1998) Gastro-intestina protein loss in late survivors of Fontan surgery and other congenital heart disease. Eur Heart J 19(3): 514-520.
188. Steffan AM, Kirn A (1986) mediated phagocytosis induced in murine Kupffer cells by "in vitro" activation with endotoxin. Gastroenterol Clin Biol C3- 10(2): 117-121.

189. Costales P, Castellano J, Revuelta-Lopez E, Cal R, Aledo R, et al (2013) Lipopolysaccharide downregulates CD91/low-density lipoprotein receptor-related protein 1 expression through SREBP-1 overexpression in human macrophages. Atheroscler 227(1): 79-88.

190. Wiesner P, Choi SH, Almazan F, Benner C, Huang W, et al. (2010) Low doses of lipopolysaccharide and minimally oxidized low density lipoprotein cooperatively activate macrophages via nuclear factor kappa B and activator protein-1: possible mechanism for acceleration of atherosclerosis by subclinical endotoxemia. Circ Res 107(1): 56-65.

191. Yang Y, Li Q, Deng Z, Zhang Z, Xu J, et al. (2011) Protection from lipopolysaccharide induced pulmonary microvascular endothelial cell injury by activation of hedgehog signaling pathway. Mol Biol Rep 38(6): 3615-3622.

192. Dayoub JC, Ortiz F, Lopez LC, Venegas C, Del Pino-Zumaquero, et al. (2011) Synergism between melatonin and atorvastatin against endothelial cell damage induced by lipopolysaccharide. J Pineal Res 51(3): 324-330.

193. Morel DW, DiCorleto PE, Chisolm GM (1986) Modulation of endotoxin-induced endothelial cell toxicity by low density lipoprotein. Lab Invest 55(4): 419-426.

194. Bellot P, Garcia-Pagan JC, Frances R, Abraldes JG, Navasa M, et al. (2010) Bacterial DNA translocation is associated with systemic circulatory abnormalities and intrahepatic endothelial dysfunction in patients with cirrhosis. Hepatol 52(6): 2044-2052.

195. Troseid M, Nestvold TK, Nielsen EW, Thoresen H, Seljeflot I, et al. (2015). Soluble CD14 is associated with markers of vascular dysfunction in bariatric surgery patients. Metabol Syndr Rel Disord 13: $119-124$

196. Brenchley JM, Price DA, Schacker TW, Asher TE, Silvestri G, et al. (2006) Microbial translocation is a cause of systemic immune activation in chronic HIV infection. Nat Med 12(12): 1365-1371.

197. Pelsers MM, Namiot Z, Kisielewski W, Namiot A, Januszkiewicz M, et al. (2003) Intestinal-type and liver-type fatty acid binding protein in the intestine. Tissue distribution and clinical utility. Clin Biochem 36(7): 529-535.

198. Ziegler TR, Luo M, Estivariz CF, Moore DA, Sitaraman SV, et al. (2008) Detectable serum flagellin and xAIM-/- lipopolysaccharide and upregulated anti-flagellin and lipopolysaccharide immunoglobulins in human short bowel syndrome. Am J Physiol Regul Integr Comp Physiol 294(2): R402-R410.

199. Moore FA, Moore EE, Poggetti RS, Read RA (1992) Post-injury shock and early bacteremia. A lethal combination. Archiv Surg 127(8): 893-897.

200. Van der Waaij DJM, Berghuis-de Vries JM, Lekkerkerk-van der Wees JEC (1971) Colonization resistance of the digestive tract and the spread of bacteria to the lymphatic organs in mice. J Hyg 70(2): 335-342.

201. Guarner F, Malagelada JR (2003) Gut flora in health and disease. Lancet 361(9356): 512-519.

202. Haidari M, Wyde PR, Litovsky S, Vela D, Ali M, et al. (2010) Influenza virus directly infects, inflames, and resides in the arteries of atherosclerotic and normal mice. Atheroscler 208(1): 90-96. 
203. Smith PD, Meng G, Salazar-Gonzalez JF, Shaw GM (2003) Macrophage HIV-1 infection and the gastrointestinal tract reservoir. J Leukoc Biol 74(5): 642-649.

204. Acheson DWK, Luccioli S (2004) Mucosal immune responses. Clin Gastroenterol 18(2): 387-404.

205. Gorski A, Weber-Dabrowska B. (2005) The potential role of endogenous bacteriophages in controlling invading pathogens. Cell Mol Life Sci 62(5): 511-519.

206. Barfoot R, Denham S, Gyure LA, Hall JG, Hobbs SM, et al. (1989) Some properties of dendritic macrophages from peripheral lymph. Immunol 68(2): 233-239.

207. Danese S, Fiocchi C (2005) Platelet activation and the CD40/CD40 ligand pathway: mechanisms and implications for human disease. Crit Rev Immunol 25(2): 103-122.

208. Janowska-Wieczorek A, Wysoczynski M, Kijowski J, Marquez-Curtis L, Machalinski B, et al. (2005) Microvesicles derived from activated platelets induce metastasis and angiogenesis in lung cancer. Int J Cancer 113(5): 752-760.

209. Gorski A, Kniotek M, Perkowska-Ptasinska A, Mroz A, Przerwa A, et al. (2006) Bacteriophages and transplantation tolerance. Transplant Proc 38(1): 331-333.

210. Wu T, Trevisan M, Genco RJ, Dorn JP, Falkner KL, et al. (2000) Periodontal disease and risk of cerebrovascular disease. The first national health and nutrition examination survey and its follow-up study. Arch Intern Med 160(18): 2749-2755.

211. Joshipura KJ, Hung KC, Rimm EB, Willett WC, Ascherio A (2003) Periodontal disease, tooth loss, and incidence of ischemic stroke. Stroke 34(1): 47-52.

212. Nagata E, de Toledo A, Oho T (2011) Invasion of human aortic endothelial cells by oral viridans group Streptococci and induction of inflammatory cytokine production. Mol Oral Microbiol 26(1): 7888.

213. Rosenfeld ME (2013) Inflammation and atherosclerosis: direct versus indirect mechanisms. Curr Opin Pharmacol 13(2):154-160.

214. Armitage GC (1999) Development of a classification system for periodontal diseases and conditions. Ann Periodontol 4(1): 1-6.

215. Williams RC (1990) Periodontal disease. N Engl JMed 322(6): 373382.

216. Hobson FG, Juel-Jensen BE (1956) Teeth, Streptococcus viridans, and subacute bacterial endocarditis. Br Med J 2(5008): 1501-1505.

217. Lick SD, Edozie SN, Woodside KJ, Conti VR (2005) Streptococcus viridans endocarditis from tongue piercing. J Emerg Med 29(1): 57 59.

218. Danesh J, Collins R, Peto R (1997) Chronic infections and coronary heart disease: is there a link? The Lancet 350(9075): 430-436.

219. Hoffmeister A, Rothenbacher D, Wanner P, Bode G, Persson K, et al. (2000) Seropositivity to Chlamydial lipopolysaccharide and Chlamydia pneumoniae, systemic inflammation and stable coronary artery disease: negative results of a case-control study. J Am Coll Cardiol 35(1): 112-118.

220. Slots J (1999) Actinobacillus actinomycetemcomitans and Porphromonas gingivalis in human periodontal disease: occurrence and treatment. Periodontol 2000 20: 82-121.
221. Tribble GD, Kerr JE, Wang BY (2013) Genetic diversity in the ora pathogen Porphyromonas gingivalis: molecular mechanisms and biological consequences. Fut Microbiol 8(5): 607-620.

222. Silver JG, Martin AW, McBride BC (1979) Experimental transient bacteraemias in human subjects with clinically healthy gingivae. J Clin Periodontol 6(1): 33-36.

223. Bender IB, Seltzer S, Tashman S, Meloff G (1963) Dental procedures in patients with rheumatic heart disease. Oral Surg Oral Med Oral Pathol 16: 466-473.

224. Baumgartner JC, Heggers JP, Harrison JW (1976) The incidence of bacteremias related to endodontic procedures I. Nonsurgical endodontics. J Endodont 2(5): 135-140.

225. Nakib SA, Pankow JS, Beck JD, Offenbacher S, Evans GW (2004) Periodontitis and coronary artery calcification: the atherosclerosis risk in communities (ARIC) study. J Periodontol 75(4): 505-510.

226. Beck JD, Slade G, Offenbacher S (2000) Oral disease, cardiovascular disease and systemic inflammation. Periodontol 2000 23: 110-120.

227. Slots J (1979) Subgingival microflora and periodontal disease. J Clin Periodontol 6(5): 351-382.

228. Debelian GJ, Olsen I, Tronstad L (1994) Systemic diseases caused by oral microorganisms. Endod Dent Traumatol 10(2): 57-65.

229. Vigueras SH, Zuniga MD, Jane-Salas E, Navarrete LS, Segura-Egea JJ, et al. (2015) Viruses in pulp and periapical inflammation: a review. Odontol 1-8.

230. Noiri Y, Li L, Ebisu S (2001) The localization of periodontal disease associated bacteria in human periodontal pockets. J Dent Res 80(10): 1930-1934.

231. Barkhordar RA, Hayashi C, Hussain MZ (1999) Detection of interleukin-6 in human dental pulp and periapical lesion. Endod Dent Traumotol 15(1): 26-27.

232. Gamonal J, Acevedo A, Bascones A, Jorge O, Silva A (2000) Levels of interleukin-1 beta, -8 , and -10 and Rantes in gingival crevicular fluid and cell population in adult periodontitis patients and the effect of periodontal treatment. J Periodontol 71: 1535-1545.

233. Thoden van Velzen SK, Abraham-Inpijn L, Moorer WR (1984) Plaque and systemic disease: a reappraisal of the focal infection concept. J Clin Periodontol 11(4):209-220.

234. Fitzsimmons TR, Sanders AE, Bartold PM, Slade GD (2010) Local and systemic biomarkers in gingival crevicular fluid increase odds of periodontitis. J Clin Periodontol 37(1): 30-36.

235. Megson E, Fitzsimmons T, Dharmapatni K, Bartold PM (2010) C-reactive protein in gingival crevicular fluid may be indicative of systemic inflammation. J Clin Periodontol 37(9): 797-804.

236. Caplan DJ, Pankow JS, Cai J, Offenbacher S, Beck JD (2009) The relationship between self-reported history of endodontic therapy and coronary heart disease in the Atherosclerosis Risk in Communities Study. J Am Dent Assoc 140(8): 1004-1012.

237. Nair PN (2004) Pathogenesis of apical periodontitis and the causes of endodontic failures. Crit Rev Oral Biol Med 15(6): 348-381.

238. Sakamoto M, Rocas IN, Siqueira JF Jr, Benno Y (2006) Molecular analysis of bacteria in asymptomatic and symptomatic endodontic infections. Oral Microbiol Immunol 21(2): 112-122. 
239. Marton I, Kiss C, Balla G, Szabo T, Karmazsin L (1988) Acute phase proteins in patients with chronic periapical granuloma before and after surgical treatment. Oral Microbiol Immunol 3(2): 95-96.

240. Miller GA, DeMayo T, Hutter JW (1996) Production of interleukin-1 by polymorphonuclear leukocytes resident in periradicular tissue. J Endod 22(7): 346-351.

241. Kuo ML, Lamster IB, Hasselgren G (1998) Host mediators in endodontic exudates. I. Indicators of inflammation and humoral immunity. J Endod 24(9): 598-603.

242. Garrido M, Dezerega A, Bordagaray MJ, Reyes M, Vernal R, et al. (2015)C-reactive protein expression is upregulated in apical lesions of endodontic origin in association with Interleukin-6. J Endod 1-6.

243. Mattila KJ, Nieminen MS, Valtonen VV, Rasi VP, Kesaniemi YA, et al (1989) Association between dental health and acute myocardial infarction. BMJ 298(6676): 779-781.

244. Genco RJ (1998) Periodontal disease and risk for myocardial infarction and cardiovascular disease. Cardiovasc rev rep 19: 34-40.

245. Dajani AS, Taubert KA, Wilson W, Bolger AF, Bayer A, et al. (1997) Prevention of bacterial endocarditis. Recommendations by the American Heart Association. Circ 96(1): 358-366.

246. Beck JD, Eke P, Heiss G, Madianos P, Couper D, et al. (2005) Periodontal disease and coronary heart disease. A reappraisal of the exposure. Circ 112(1): 19-24.

247. Spahr A, Klein E, Khuseyinova N, Boeckh C, Muche R, et al. (2006) Role of periodontal bacteria and importance of total pathogen burden in the coronary event and periodontal disease (CORODONT). Arch Intern Med 166(5): 554-559.

248. Moazed TC, Kuo C, Grayston JT, Campbell LA (1998) Evidence of systemic dissemination of Chlamydia pneumoniae via macrophages in the mouse. J Infect Dis 177(5): 1322-1325.

249. Kozarov EV, Dorn BR, Shelburne CE, Dunn Jr WA, Progulske-Fox A (2005) Human atherosclerotic plaque contains viable invasive Actinobacillus actinomycetemcomitans and Porphyromonas gingivalis. Arterioscler Thromb Vasc Biol 25(3): e17-e18.

250. Maass M, Bartels C, Kruger S, Krause E, Engel PM (1998) Endovascular presence of Chlamydia pneumoniae DNA is a generalized phenomenon in atherosclerotic vascular disease. Atheroscler 140(1): S25-S30.

251. Pasqualini D, Bergandi L, Palumbo L, Borraccino A, Dambra V, et al. (2012) Association among oral health, apical periodontitis, CD14 polymorphisms, and coronary heart disease in middle-aged adults. J Endod 38(12): 1570-1577.

252. Caplan DJ, Chasen JB, Krall EA, Cai J, Kang S (2006) Lesions of endodontic origin and risk of coronary heart disease. J Dent Res 85(11): 996-1000

253. Debelian GJ, Eribe ER, Olsen I, Tronstad L (1997) Ribotyping of bacteria from root canal and blood of patients receiving endodontic therapy. Anaerobe 3(4): 237-243.

254. Debelian GJ, Olsen I, Tronstad . (1998) Anaerobic bacteraemia and fungemia in patients undergoing endodontic therapy: an overview. Ann Periodontol 3(1): 281-287.

255. Siqueira Jr JF, Rocas IN (2014) Present status and future directions in endodontic microbiology. Endod Topics 30: 3-22.

256. Robinson L, Kraus FW, Lazansky JP (1950) Bacteraemias of dental origin. A study of the factors influencing occurrence and detection. Oral Surg Oral Med Oral Pathol 3: 923-936.
257. Durack DT (1985) Current issues in prevention of infective endocarditis. American J Med 78(6B): 149-156.

258. Seymour RA, Lowry R, Whitworth JM, Martin MV (2000) Infective endocarditis, dentistry and antibiotic prophylaxis; time to rethink? British Dent J 189(11): 610-616.

259. Durack DT (1994) Infective and non-infective endocarditis. In: Hurst JW, The Heart, Arteries and Veins. McGraw Hill, New York, USA, pp. 1681-1704.

260. Li H, Chen V, Chen Y, Baumgartner JC, Machida CA (2009) Herpesviruses in endodontic pathoses: association of Epstein-Barr virus with irreversible pulpitis and apical periodontitis. J Endod 35(1): 23-29.

261. Kalayoglu MV, Byrne GI (1998) of Induction macrophage foam cell formation by Chlamydia pneumoniae. J Infect Dis 177(3): 725-729.

262. Lakio L, Lehto M, Tuomainen AM, Jauhiainen M, Malle E, et al. (2006) Pro-atherogenic properties of lipopolysaccharide from the periodontal pathogen Actinobacillus actinomycetemcomitans. Innate Immun 12(1): 57-64.

263. Belland RJ, Ouellette SP, Gieffers J, Byrne GI (2004) Chlamydia pneumoniae and atherosclerosis. Cell Microbiol 6(2): 117-127.

264. Stocker CJ, Sugars KL, Harari OA, Landis RC, Morley BJ, et al. (2000) TNF- $\alpha$, IL- 4 , and IFN- $\gamma$ regulate differential expression of P- and E-Selectin expression by porcine aortic endothelial cells. J Immunol 64: 3309-3315.

265. Osborn L, Hession C, Tizard R, Vassallo C, Luhowskyj S, et al. (1989) Direct expression and cloning of vascular cell adhesion molecule 1 , a cytokine-induced endothelial protein that binds to lymphocytes. Cell 59(6): 1203-1211.

266. Ameriso SF, Fridman EA, Leiguarda RC, Sevlever GE (2001) Detection of Helicobacter pylori in human carotid atherosclerotic plaques. Stroke 32(2): 385-391.

267. Tonetti MS, D’Aiuto F, Nibali L, Donald A, Storry C, et al. (2007) Treatment of periodontitis and endothelial function. N Engl J Med 356(9): 911-920.

268. Pischon N, Heng N, Bernimoulin JP, Kleber BM, Willich SN, et al. (2007) Obesity, inflammation, and periodontal disease. J Dent Res 86(5): 400-409.

269. Kaukoranta-Tolvanen SE, Teppo AM, Laitinen K, Saikku P, Linnavuori $\mathrm{K}$, et al. (1996) Growth of Chlamydia pneumoniae in cultured human peripheral blood mononuclear cells and induction of a cytokine response. Microbial Path 21(3): 215-221.

270. Schumacher A, Seljeflot I, Lerkerød AB, Sommervoll L, Otterstad JE (2002) Positive Chlamydia pneumoniae serology is associated with elevated levels of tumor necrosis factor alpha in patients with coronary heart disease. 164(1): 153-160.

271. Tuomainen AM, Hyvarinen K, Ehlers PI, Mervaala E, Leinonen M, et al. (2011) The effect of proatherogenic microbes on macrophage cholesterol homeostasis in apoE-deficient mice. Microbial Path 51: 217-224.

272. Hardardottir I, Moser AH, Memon R, Grunfeld C, Feingold KR (1994) Effects of TNF, IL-1, and the combination of both cytokines on cholesterol metabolism in Syrian hamsters. Lymphokine Cytokine Res 13(3): 161-166.

273. Pussinen PJ, Malle E, Metso J, Sattler W, Raynes JG (2001) Acutephase HDL in phospholipid transfer protein (PLTP)-mediated HDL conversion. Atheroscler 155(2): 297-305. 
274. Skretting G, Gjernes E, Prydz H (1995) Regulation of lecithin: Cholesterol acyltransferase by TGF- $\beta$ and interleukin-6. Biochim Biophys Acta- Lipids Lipid Metabol 1255: 267-272.

275. Roberts-Thompson KF, Spencer AJ (1999) Public knowledge of the prevention of dental decay and gum diseases. Aust Dent J 44: 253 258.

276. Raines EW, Ferri N (2005) Thematic review series: the immune system and atherogenesis, cytokines affecting endothelial and smooth muscle cells in vascular disease. J Lipid Res 46: 1081-1092.

277. Gerdes N, Sukhova GK, Libby P, Reynolds RS, Young JL, et al. (2002) Expression of interleukin (IL)-18 and functional IL-18 receptor on human vascular endothelial cells, smooth muscle cells, and macrophages: implications for atherogenesis. J Exp Med 195(2): 245-257.

278. Galis ZS, Sukhova GK, Lark MW, Libby P (1994) Increased expression of matrix metalloproteinases and matrix degrading activity in vulnerable regions of human atherosclerotic plaques. J Clin Invest 94(6): 2493-2503.

279. Libby P, Theroux P (2005) Pathophysiology of coronary artery disease. Circ 111(25): 3481-3488.

280. Yasmin, McEniery CM, Wallace S, Dakham Z, Pulsalkar P, et al. (2005) Matrix metalloproteinase-9 (MMP-9), MMP-2, and serum elastase activity are associated with systolic hypertension and arterial stiffness. Arterioscler Thromb Vasc Biol 25(2): 372.

281. Tayebjee MH, Lip GY, Tan KT, Patel JV, Hughes EA, et al. (2005) Plasma matrix metalloproteinase-9, tissue inhibitor of metalloproteinase-2, and CD40 ligand levels in patients with stable coronary artery disease. Am J Cardiol 96(3): 339-345.

282. Noji Y, Kajinami K, Kawashiri MA, Todo Y, Horita T, et al. (2001) Circulating matrix metalloproteinases and their inhibitors in premature coronary atherosclerosis. Clin Chem Lab Med 39(5): 380-384.

283. Kai H, Ikeda H, Yasukawa H, Kai M, Seki Y, et al. (1998) Periphera blood levels of matrix metalloproteases-2 and -9 are elevated in patients with acute coronary syndromes. J Am Coll Cardiol 32: 368372

284. Inokubo Y, Hanada $H$, Ishizaka H, Fukushi T, Kamada T, et al. (2001) Plasma levels of matrix metalloproteinase- 9 and tissue inhibitor of metalloproteinase- 1 are increased in the coronary circulation in patients with acute coronary syndrome. Am Heart J 141(2):211217.

285. Van Deventer SJ, Buller HR, ten Cate JW, Aarden LA, Hack CE ( 1990) Experimental endotoxemia in humans: analysis of cytokine release and coagulation, fibrinolytic, and complement pathways. Blood 76 (12):2520-2526

286. Beck J, Garcia R, Heiss G, Vokonas PS, Offenbacher S, et al. (1996) Periodontal disease and cardiovascular disease. J Periodontol 67: 1123-1137.

287. Fisher EA, Feig JE, Hewing B, Hazen SL, Smith JD (2012) Highdensity lipoprotein function, dysfunction, and reverse cholesterol transport. Arterioscler Thromb Vasc Biol 32:2813-2820.

288. Deshpande RG, Khan MB, Genco CA (1998) Invasion of aortic and heart endothelial cells by Porphyromonas gingivalis. Infect Immun 66(11): 5337-5343.

289. Haraszthy V, Zambon J, Trevisan M (2000) Identification of periodontal pathogens in atheromatous plaques. J Periodontol 71(10): 1554-1560.
290. Kuramitsu HK, Qi M, Kang I, Chen W (2001) Role of periodontal bacteria in cardiovascular diseases. Ann Periodontol 6(1): 41-47.

291. McEcoy LM, Sun H, Tsao PS, Cooke JP, Berliner JA, et al. (1997) Novel vascular molecule involved in monocyte adhesion to aortic endothelium in models of atherogenesis. J Exp Med 185(12): 20692077.

292. Schneeberger PM, van Langevelde P, van Kessel KP, VandenbrouckeGrauls CM, Verhoef J, et al. (1994) Lipopolysaccharide induces hyperadhesion of endothelial cells for neutrophils leading to damage. Shock 2(4): 296-300.

293. Libby P, Ordovas JM, Birinyi LK, Auger KR, Dinarello CA, et al. (1986) Inducible interleukin-1 gene expression in human vascular smooth muscle cells. J Clin Invest 78(6): 1432-1438.

294. Fleet JC, Clinton SK, Salomon RN, Loppnow H, Libby P, et al. (1992) Atherogenic diets enhance endotoxin-stimulated interleukin-1 and tumor necrosis factor gene expression in rabbit aortae. J Nutr 122(2): 294-305.

295. Pajkrt D, Lerch PG, van der Poll T, Levi M, et al. (1997) Differential effects of reconstituted high-density lipoprotein on coagulation, fibrinolysis and platelet activation during human endotoxemia. Thromb Haemost 77(2): 303-307.

296. Doherty DE, Zagarella L, Henson PM, Worthen GS (1989) Lipopolysaccharide stimulates monocyte adherence by effects on both the monocyte and the endothelial cell. J Immunol 143(11): 3673-3679.

297. Kalinina N, Agrotis A, Antropova Y, DiVitto G, Kanellakis P, et al (2004) Increased expression of the DNA-binding cytokine HMGB1 in human atherosclerotic lesions: role of activated macrophages and cytokines. Arterioscler Thromb Vasc Biol 24(12): 2320-2325.

298. Mullins GE, Sunden-Cullberg J, Johansson AS, Rouhiainen A, Erlandsson-Harris $\mathrm{H}$, et al. (2004) Activation of human umbilical vein endothelial cells leads to relocation and release of high mobility group box chromosomal protein 1 . Scand J Immunol 60(6): 566-573.

299. Porto A, Palumbo R, Pieroni M, Aprigliano G, Chiesa R, et al. (2006) Smooth muscle cells in human atherosclerotic plaques secrete and proliferate in response to high mobility group box 1 protein. FASEB J 20(14): 2565-2566.

300. Hopkins PN (2013) Molecular biology of atherosclerosis. Physio Rev 93(3): 1317-1542.

301. Edfeldt K, Swedenborg J, Hansson GK, Yan Z (2002) Expression of Toll-like receptors in human atherosclerotic lesions: a possible pathway for plaque activation. Circ 105(10): 1158-1161.

302. Swirski FK, Pittet MJ, Kircher MF, Aikawa E, Jaffer FA (2006) Monocyte accumulation in mouse atherogenesis is progressive and proportional to extent of disease. Proc Natl Acad Sci USA 103(27): 10340-10345.

303. Lee J, Lim E, Park D, Lee S, Kim J, et al. (2008) A combination of Lox-1 and Nox1 regulates TLR9-mediated foam cell formation. Cell Signal 20(12): 2266-2275.

304. Yajima N, Takahashi M, Morimoto H, Shiba Y, Takahashi Y, et al. (2008) Critical role of bone marrow apoptosis-associated specklike protein, an inflammasome adaptor molecule, in neointimal formation after vascular injury in mice. Circ 117(24): 3079-3087.

305. Molmeret M, Kwaik YA (2002) How does Legionella pneumophila exit the host cell? Trends Microbiol 10(6): 258-260. 
306. Hertzén E, Johansson L, Wallin R, Schmidt H, Kroll M, et al. (2010) M1 protein-dependent intracellular trafficking promotes persistence and replication of Streptococcus pyogenes in macrophages. J Innate Immun 2(6): 534-545.

307. Hybiske K, Stephens RS (2007) Mechanisms of host cell exit by the intracellular bacterium Chlamydia. Proc Natl Acad Sci USA 104(27): 11430-11435

308. Atamaniuk J, Kopecky C, Skoupy S, Saemann MD, Weichhart T (2012) Apoptotic cell-free DNA promotes inflammation in haemodialysis patients. Nephrol Dial Transplant 27(3): 902-905.

309. Kuwahata S, Fujita S, Orihara K, Hamasaki S, Oba R, et al. (2010) High expression level of Toll-like receptor 2 on monocytes is an important risk factor for arteriosclerotic disease. Atheroscler 209(1): 248-254.

310. Mizoguchi E, Orihara K, Hamasaki S, Ishida S, Kataoka T, et al. (2007) Association between Toll-like receptors and the extent and severity of coronary artery disease in patients with stable angina. Coron artery dis 18(1): 31-38.

311. Monaco C, Gregan SM, Navin TJ, Foxwell BMJ, Davies AH, et al. (2009) Toll-like receptor 2 mediates inflammation and matrix degradation in human atherosclerosis. Circ 120(24): 2462-2469.

312. Ono S, Tsujimoto H, Yamauchi A, Hiraki S, Takayama E, et al. (2005) Detection of microbial DNA in the blood of surgical patients for diagnosing bacterial translocation. World J Surg 29(4): 535-539.
313. Minick CR, Fabricant CG, Fabricant J, Litrenta MM (1979) Atheroarteriosclerosis induced by infection with a herpesvirus. Am J Pathol 96(3): 673-706.

314. Zhu J, Quyyumi AA, Norman JE, Costello R, Csako G (2000) The possible role of Hepatitis A virus in the pathogenesis of atherosclerosis. J Infect Dis 182(6): 1583-1587.

315. Gyorkey F, Melnick JL, Guinn GA, Gyorkey P, DeBakey ME, et al (1984) Herpesviridae in the endothelial and smooth muscle cells of the proximal aorta in arteriosclerotic patients. Exp Mol Pathol 40(3): 328-339.

316. Nicholson AC, Hajjar DP (1998) Herpesviruses in atherosclerosis and thrombosis Etiologic agents or ubiquitous bystanders? Arteriosclerosis, Arterioscler Thromb Vasc Biol 18(3): 339-348.

317. Eryol NK, Kiliç H, Gül A, Ozdogru I, Inanç T, et al. (2005) Are the high levels of cytomegalovirus antibodies a determinant in the development of coronary artery disease? Int Heart J 46(2): 205-209.

318. Gredmark S, Gredmark S, Jonasson L, Gosliga DV, Ernerudh J, (2007) Active cytomegalovirus replication in patients with coronary disease. Scand Cardiovasc J 41(4): 230-234. 